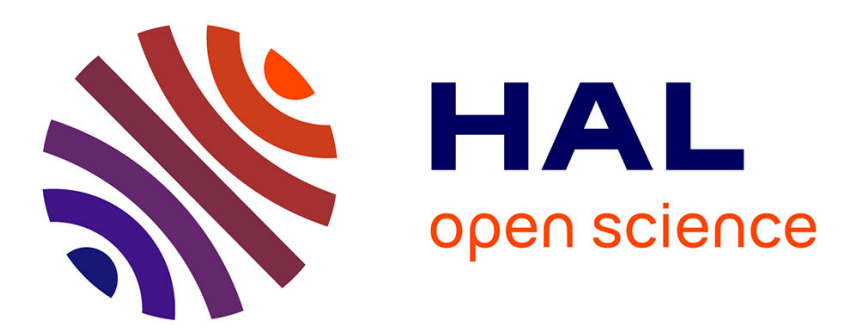

\title{
Combustion synthesis and up-conversion luminescence of La2O2S:Er3+,Yb3+ nanophosphors
}

Noha Hakmeh, Christophe Chlique, Odile Merdrignac-Conanec, Bo Fan, François Cheviré, Xianghua Zhang, Xianping Fan, Xusheng Qiao

\section{To cite this version:}

Noha Hakmeh, Christophe Chlique, Odile Merdrignac-Conanec, Bo Fan, François Cheviré, et al.. Combustion synthesis and up-conversion luminescence of La2O2S:Er3+,Yb3+ nanophosphors. Journal of Solid State Chemistry, 2015, 226, pp.255-261. 10.1016/j.jssc.2015.02.015 hal-01131935

\author{
HAL Id: hal-01131935 \\ https://hal.science/hal-01131935
}

Submitted on 29 Oct 2015

HAL is a multi-disciplinary open access archive for the deposit and dissemination of scientific research documents, whether they are published or not. The documents may come from teaching and research institutions in France or abroad, or from public or private research centers.
L'archive ouverte pluridisciplinaire HAL, est destinée au dépôt et à la diffusion de documents scientifiques de niveau recherche, publiés ou non, émanant des établissements d'enseignement et de recherche français ou étrangers, des laboratoires publics ou privés. 


\title{
Combustion synthesis and up-conversion luminescence of $\mathrm{La}_{2} \mathrm{O}_{2} \mathrm{~S}: \mathbf{E r}^{3+}, \mathrm{Yb}^{3+}$ nanophosphors
}

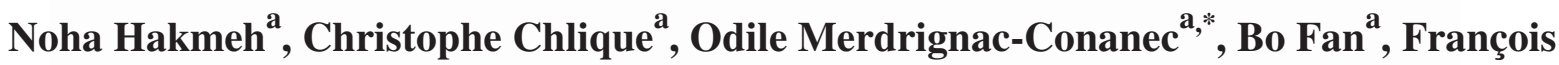
Cheviré $^{\mathrm{a}}$, Xianghua Zhang ${ }^{\mathrm{a}}$, Xianping Fan ${ }^{\mathrm{b}}$, Xusheng Qiao ${ }^{\mathrm{b}}$

${ }^{\mathrm{a}}$ Equipe Verres et Céramiques, UMR CNRS 6226, Université de Rennes 1, Campus Beaulieu, 35042 Rennes Cedex, France

${ }^{\mathrm{b}}$ Department of Materials Science and Engineering, Zhejiang University, Hangzhou 310027 , People's Republic of China

\begin{abstract}
$\mathrm{La}_{2} \mathrm{O}_{2} \mathrm{~S}: \mathrm{Er}^{3+}, \mathrm{Yb}^{3+}$ nanocrystalline up-converting phosphors were synthesized by a combustion method at low temperature, using ethanol as pre-ignition fuel and thioacetamide as sulfurizing agent and organic fuel. The phosphors were characterized by powder X-ray diffractometry, scanning electron microscopy, UV/Vis/NIR spectroscopy and fluorescence spectroscopy. Pure and well-crystallized $\mathrm{La}_{2} \mathrm{O}_{2} \mathrm{~S}: \mathrm{Er}^{3+}, \mathrm{Yb}^{3+}$ nanoparticles, of the order of 50-200 nm, are obtained after a post-treatment in a $\mathrm{H}_{2} \mathrm{~S} / \mathrm{N}_{2}$ flow for $2 \mathrm{~h}$ at $1000^{\circ} \mathrm{C}$. The efficient energy transfer from $\mathrm{Yb}^{3+}$ to $\mathrm{Er}^{3+}$ results in a strong up-conversion upon excitation at $980 \mathrm{~nm}$. The emission spectra show the intense green emissions corresponding to the $\left({ }^{2} \mathrm{H}_{11 / 2},{ }^{4} \mathrm{~S}_{3 / 2}\right) \rightarrow{ }^{4} \mathrm{I}_{15 / 2}$ transitions and a red emission corresponding to the ${ }^{4} \mathrm{~F}_{9 / 2} \rightarrow{ }^{4} \mathrm{I}_{15 / 2}$ transition. Additionally, within the investigated codoping concentrations, no significant concentration quenching effect and back energy transfer from $\mathrm{Er}^{3+}$ to $\mathrm{Yb}^{3+}$ were evidenced. This research highlights the influence of the sulfurization treatment on the purity/crystallinity/morphology of the nanocrystals and the luminescence efficiency.
\end{abstract}

KEYWORDS: Lanthanum oxysulfide, Combustion synthesis, Luminescence, Rare-earth, Upconversion

*Corresponding author. Tel: + 33 (0)2 2323 62 66/Fax: + 33 (0)2 23235683

Email address: odile.merdrignac@univ-rennes1.fr (O. Merdrignac-Conanec). 


\section{Introduction}

Over the past decade, up-conversion has attracted intense research interest for its potential applications in biomedical imaging [1-4] and wavelength converters for solar cells [5,6]. Besides a good chemical stability, a basic request for the host material is that its phonon energy is low since up-conversion efficiency is determined by the nonradiative relaxation. Most commonly used host lattices so far are halides and oxides. Halides such as fluoride-based Up-Conversion NanoParticles (UCNPs) (e.g. $\mathrm{NaYF}_{4}$ :Er,Yb) have been identified as ones of the most efficient up-conversion phosphors due to their low phonon vibration energy $\left(<400 \mathrm{~cm}^{-1}\right)$. However, their toxicity and air-sensitivity have limited their industrial applications. On the other hand, oxidebased lattices have better chemical stability but they suffer from relatively high phonon energy $\left(>500 \mathrm{~cm}^{-1}\right)[7,8]$. Rare-earth oxysulfides $\left(\mathrm{R}_{2} \mathrm{O}_{2} \mathrm{~S}\right)$ are well known for their potential applications as luminescent host materials. For instance, rare-earth doped $\mathrm{R}_{2} \mathrm{O}_{2} \mathrm{~S}$ oxysulfides are effective phosphors such as the red emitter under cathode-ray excitation (e.g. $\mathrm{Y}_{2} \mathrm{O}_{2} \mathrm{~S}$ :Eu) applied in TV field [9] and are also extensively studied as laser materials in the form of single crystals [10,11] or ceramics [12]. Considering their relatively low phonon energy $\left(\sim 500 \mathrm{~cm}^{-1}\right)$ due to sulfur atoms, good chemical/thermal stability due to oxygen atoms and low toxicity $[8,13]$, mixed-anions materials like rare-earth oxysulfides are therefore promising hosts for up-conversion. They combine many favorable properties, especially for biomedical imaging which requires a stable material and a transparency of the host material in the visible to avoid overlapping luminescence. Conventional phosphors for biomedical imaging, such as quantum dots, gold nanoparticles, organic fluorophores and luminescent transition metal complexes present important drawbacks like low photostability, autofluorescence, limited detection sensitivity and cytotoxicity $[14,15]$. In contrast, inorganic lanthanide-doped UCNPs offer the advantage of being photoexcitable in the NIR, rather than in UV, where the auto-absorption of biological tissue is weak, thereby 
significantly minimizing background autofluorescence and allowing higher detection sensitivity [7]. In addition these phosphors offer a deeper NIR light penetration into biological tissue causing less photodamage to DNA/RNA of the biological samples due to lower excitation light energy, an improved stability against photobleaching, photoblinking and photochemical degradation and a lower cytotoxicity [16].

The $\mathrm{Er}^{3+}-\mathrm{Yb}^{3+}$ couple is an effective up-conversion couple in which the energy transfer was demonstrated for the first time in 1966 by Auzel in CaWO4 [17,18]. Up-conversion can take place through direct (resonant) energy transfer from $\mathrm{Yb}^{3+}$ to $\mathrm{Er}^{3+}$. Energy levels of $\mathrm{Er}^{3+}$ having sufficiently large gaps to the next lowest level together with long-lived excited states make radiative relaxation more likely than multiphonon relaxation [19].

The conventional way to prepare $\mathrm{R}_{2} \mathrm{O}_{2} \mathrm{~S}$ is the solid state reaction with or without flux agent [13,20-25]. Reduction of rare-earth oxysulfates under hydrogen-helium mixture or sulfurization of rare-earth oxides or other precursors (e.g. carbonates) under $\mathrm{H}_{2} \mathrm{~S}, \mathrm{CS}_{2}$ or $\mathrm{S}$ vapor can also lead to $\mathrm{R}_{2} \mathrm{O}_{2} \mathrm{~S}$ [26,27]. However, all the above methods involve high temperatures and long-term annealing and thus produce coarse powders. To meet the increasing requirement of high resolution display and high quantum efficiency, $\mathrm{R}_{2} \mathrm{O}_{2} \mathrm{~S}$ nanocrystals are needed [28,29]. These "nano-techniques" include: i) solvothermal pressure-relief process in ethanol media [30], ii) gelnetwork coprecipitation method using gelatin as the template and ammonium sulfate as the sulfurizing agent at relatively low temperatures $\left(750^{\circ} \mathrm{C}\right)$ in a $\mathrm{H}_{2}$ atmosphere [31], iii) two step sol-gel polymer thermolysis method [32], iv) and combustion method [33-38].

Among these nano-techniques, the combustion synthesis technique offers the possibility to produce homogeneous, crystalline, multi-component, fine powders at considerably lower temperatures and with significantly reduced processing time (in a few minutes or even seconds). However, the fast reaction rate usually reduces the crystallinity of the products and introduces 
residual byproducts that are detrimental for the luminescence. A suitable post-treatment is often required to eliminate these occurrences without inducing uncontrollable crystal growth.

The objective of this study is therefore to investigate the synthesis of nanocrystalline $\mathrm{Er}^{3+}, \mathrm{Yb}^{3+}$ activated $\mathrm{La}_{2} \mathrm{O}_{2} \mathrm{~S}$ by combustion method and evaluate their up-conversion efficiency. To the best of our knowledge, we report, for the first time, the preparation of $\mathrm{La}_{2} \mathrm{O}_{2} \mathrm{~S}$ : Yb,Er upconverter phosphors via a combustion method. A sulfurization post-treatment was carried out under $\mathrm{H}_{2} \mathrm{~S} / \mathrm{N}_{2}$ flow. Its effects on morphology, composition and luminescence properties of the phosphors were studied.

\section{Experimental}

\subsection{Preparation of $\mathrm{Yb}^{3+}, \mathrm{Er}^{3+}$ co-doped lanthanum oxysulfide}

The starting materials $\mathrm{La}\left(\mathrm{NO}_{3}\right)_{3}, 6 \mathrm{H}_{2} \mathrm{O}$ (Alfa Aesar, 99.9\%), $\mathrm{Er}\left(\mathrm{NO}_{3}\right)_{3}, 5 \mathrm{H}_{2} \mathrm{O}$ (Aldrich, 99.9\%), $\mathrm{Yb}\left(\mathrm{NO}_{3}\right)_{3}, 5 \mathrm{H}_{2} \mathrm{O}$ (Aldrich, 99.9\%) and thioacetamide (TAA) $\mathrm{CH}_{3} \mathrm{CSNH}_{2}$ (Aldrich $\geq 99.9 \%$ ) were dissolved with absolute ethanol (Prolabo, Normapur). Stoichiometric lanthanum nitrate/fuel (TAA) molar ratio was used in all preparations. The co-doping concentrations investigated are listed in Table 1.

Table 1

$\mathrm{Er}^{3+}, \mathrm{Yb}^{3+}$ co-doping concentrations $(\mathrm{mol} \%)$ in $\mathrm{La}_{2} \mathrm{O}_{2} \mathrm{~S}$ powders.

\begin{tabular}{lll}
\hline Sample & $\mathrm{Er}(\mathrm{mol} \%)$ & $\mathrm{Yb}(\mathrm{mol} \%)$ \\
\hline $\mathrm{Er}_{0.01} \mathrm{Yb}_{0.0}$ & 1 & 0 \\
$\mathrm{Er}_{0.01} \mathrm{Yb}_{0.01}$ & 1 & 1 \\
$\mathrm{Er}_{0.01} \mathrm{Yb}_{0.02}$ & 1 & 2 \\
$\mathrm{Er}_{0.01} \mathrm{Yb}_{0.03}$ & 1 & 3 \\
$\mathrm{Er}_{0.01} \mathrm{Yb}_{0.04}$ & 1 & 4 \\
\hline
\end{tabular}

The solution was heated below $80^{\circ} \mathrm{C}$ to allow the dissolution of thioacetamide. The preparation was then introduced into a muffle furnace (Thermolyne 48000 ) pre-heated to $500^{\circ} \mathrm{C}$. The ignition of ethanol first produced a yellow flame getting through the chimney of the furnace 
for few minutes. Then, a quick second flame due to the exothermic decomposition of the organic fuel took place, leading to a temperature increase and the reaction between the precursors. The beaker was kept at $500^{\circ} \mathrm{C}$ after the reaction for a few minutes to obtain a homogeneous white powder. The as-prepared powder was then ground and treated in a tubular furnace under $\mathrm{H}_{2} \mathrm{~S} / \mathrm{N}_{2}$ (10:90) flow at $1000^{\circ} \mathrm{C}$ for 2 hours.

\subsection{Characterizations}

$\mathrm{X}$-ray diffraction $(\mathrm{XRD})$ patterns were recorded at room temperature in the $2 \theta$ range 10 $70^{\circ}$ with a step size of $0.026^{\circ}$ and a scan time per step of $40 \mathrm{~s}$ using a PANalytical X'Pert Pro diffractometer ( $\mathrm{Cu} K \bar{\alpha}$ radiation, $\lambda=1.5418 \AA$, PIXcel 1D detector). Data Collector and HighScore Plus softwares were used, respectively, for recording and analysis of the patterns. The powder XRD patterns for Rietveld refinements and crystallites size estimations were recorded at room temperature in the $2 \theta$ range $5-120^{\circ}$ with a step size of $0.026^{\circ}$ and a scan time per step of $400 \mathrm{~s}$. All calculations were carried out with Fullprof program [39]. The pseudo-Voigt profile function was used and the background was approximated by linear interpolation between a set of background points. The lattice parameters were obtained from Rietveld refinements considering the space group P $3 \mathrm{~m} 1$ ( $\left.\mathrm{N}^{\circ} 164\right)$. Sulfur, oxygen and lanthanides atoms were positioned at the $1 a$ $(0,0,0), 2 d(1 / 3,2 / 3, \mathrm{z} \approx 0.63)$ and $2 d(1 / 3,2 / 3, \mathrm{z} \approx 0.28)$ atomic positions respectively with full site occupancy as starting parameters for the refinement for all analyzed samples [40].

Lanthanum, Erbium and Ytterbium were considered occupying the same crystallographic site with respective site occupancies calculated from the initial doping amount in $\mathrm{Er}^{3+}$ and $\mathrm{Yb}^{3+}$. The same thermal parameter was applied for all lanthanide atoms and the site occupancies were not refined. The estimated standard deviations (ESD) were corrected using the Berar and Lelann coefficient calculated from the structure refinement [41,42]. For each sample, the average crystallites sizes were estimated from a global profile fit without structural constraints (Le Bail) on the whole diffraction pattern $\left(6^{\circ}<2 \theta<120^{\circ}\right)$ using the elementary pseudo-Voigt function (PV), the Gaussian approximation and the following Scherrer equation (1) [43]:

$\beta_{L}=\frac{\lambda}{<L>\cdot \cos \theta}(1)$

where $\mathrm{B}_{\mathrm{L}}$ is the crystallite sizes contribution to the integral width and $<\mathrm{L}>$ is the average size of the crystallites.

The Fourier transform infrared (FTIR) transmittance spectra were recorded between 400 and $4000 \mathrm{~cm}^{-1}$ using the spectrometer Nicolet 380 (FT-IR of Thermo Electron Corporation) and treated with OMNIC software. For these measurements, the sample powders were diluted in $\mathrm{KBr}$ pellets. 
Thermogravimetric analyses (TGA) were carried out in a SDT 2960 TA instrument. The powdered samples were heated to $1000^{\circ} \mathrm{C}$ in a Pt crucible in flowing $\mathrm{N}_{2}(1.8 \mathrm{~L} / \mathrm{h})$ at a heating rate of $10^{\circ} \mathrm{C} \cdot \mathrm{min}^{-1}$. The low $\mathrm{N}_{2}$ flow rate was used to prevent deposition on the furnace walls during the heat treatment; its influence on the oxidation levels of the samples is negligible.

The grain size and morphology of the samples were observed by scanning electron microscopy (SEM) using a JEOL JSM-6301F equipment.

The transmittance spectra were recorded in $\mathrm{KBr}$ pellets ( 8 weight $\%$ ) by a double-beam spectrophotometer Perkin Elmer Lambda 1050 UV/Vis/NIR URA from ultraviolet to nearinfrared. The up-conversion luminescence (UPL) spectra were recorded by an Edinburgh FLSP920P fluorescence spectrometer. A $980 \mathrm{~nm}$ radiation from a laser diode was used as excitation source for up-conversion luminescence measurements. A NIR PMT was used for NIR region. A microsecond xenon flash-lamp $\mu \mathrm{F} 900 \mathrm{H}$ was used as light source for decay curve measurements. Visible emissions were detected by a Hamamatsu R928 PMT. All the measurements were performed at room temperature.

\section{Results and discussion}

\subsection{Materials characterization}

The experimental results evidenced that lanthanum nitrate reacts very fast (in a few seconds) with thioacetamide, producing a white powder. The XRD patterns of the powders with different doping concentrations are very similar, so that only the XRD patterns of $\mathrm{La}_{2} \mathrm{O}_{2} \mathrm{~S}: \mathrm{Er}_{0.1} \mathrm{Yb}_{0.04}$ powders before and after sulfurization are presented in Fig. 1. 


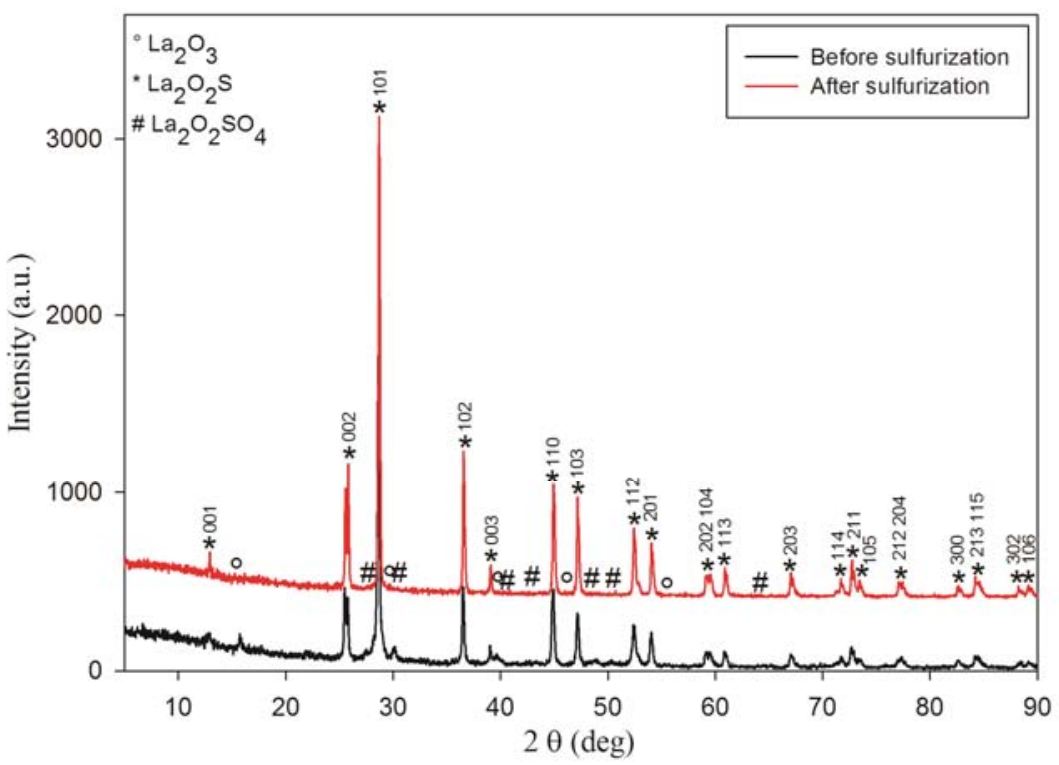

Fig.1. XRD patterns of $\mathrm{La}_{2} \mathrm{O}_{2} \mathrm{~S}: \mathrm{Er}_{0.1} \mathrm{Yb}_{0.04}$ powders before and after sulfurization

The pattern of the as-prepared powder (before sulfurization) indicates the formation of a major phase $\mathrm{La}_{2} \mathrm{O}_{2} \mathrm{~S}$ (JCPDS card $\mathrm{n}^{\circ} 75-1930$ ) with small amounts of intermediate oxysulfate phase $\mathrm{La}_{2} \mathrm{O}_{2} \mathrm{SO}_{4}$ (JCPDS card $\mathrm{n}^{\circ}$ 85-1535) and oxide phase $\mathrm{La}_{2} \mathrm{O}_{3}$ (JCPDS card $\mathrm{n}^{\circ}$ 74-1144). After a $2 \mathrm{~h}$ post-annealing treatment at $1000^{\circ} \mathrm{C}$ under $\mathrm{H}_{2} \mathrm{~S} / \mathrm{N}_{2}$, the diffraction peaks of the minor phases $\mathrm{La}_{2} \mathrm{O}_{2} \mathrm{SO}_{4}$ and $\mathrm{La}_{2} \mathrm{O}_{3}$ disappear and those of $\mathrm{La}_{2} \mathrm{O}_{2} \mathrm{~S}$ are intensified. Therefore pure and well-crystallized $\mathrm{La}_{2} \mathrm{O}_{2} \mathrm{~S}$ powders are obtained after sulfurization. All the prepared rare-earth doped $\mathrm{La}_{2} \mathrm{O}_{2} \mathrm{~S}$ samples crystallize in the hexagonal space group $\mathrm{P} 3 \mathrm{~m} 1\left(\mathrm{~N}^{\circ} 164\right)$. The crystal structure corresponds to the $\mathrm{A}-\mathrm{R}_{2} \mathrm{O}_{3}$ structural type of cerium subgroup rare earth oxides, with substitution of oxygen by sulfur on the 1a Wyckoff position while oxygen occupy the $2 \mathrm{~d}$ Wyckoff position leading to a $7(4 \mathrm{O}+3 \mathrm{~S})$ fold coordination for the rare-earth cations. Details of the Rietveld refinements and average crystallites size for the $\mathrm{La}_{2} \mathrm{O}_{2} \mathrm{~S}: 1 \% \mathrm{Er}, \mathrm{x} \% \mathrm{Yb}$ are listed in Table 2. Final Rietveld refinement patterns and atomic parameters are presented in Fig. 2 and Table 3 for the undoped sample $\mathrm{La}_{2} \mathrm{O}_{2} \mathrm{~S}: 1 \% \mathrm{Er}, 0 \% \mathrm{Yb}$ and in Fig. 3 and Table 4 for the doped sample $\mathrm{La}_{2} \mathrm{O}_{2} \mathrm{~S}: 1 \% \mathrm{Er}, 3 \% \mathrm{Yb}$.

Table 2

Details of the Rietveld refinement and average crystallites size for the $\mathrm{La}_{2} \mathrm{O}_{2} \mathrm{~S}: 1 \% \mathrm{Er}, \mathrm{x} \% \mathrm{Yb}$

\begin{tabular}{|c|c|c|c|c|c|}
\hline Yb (\%) & $0 \%$ & $1 \%$ & $2 \%$ & $3 \%$ & $4 \%$ \\
\hline Lattice & & & & & \\
\hline $\mathrm{a}(\AA)$ & $4.0506(1)$ & $4.0495(1)$ & $4.0487(1)$ & $4.0475(1)$ & $4.0470(2)$ \\
\hline$c(\AA)$ & $6.9456(1)$ & $6.9444(2)$ & $6.9437(2)$ & $6.9426(3)$ & $6.9423(3)$ \\
\hline Volume $\left(\AA^{3}\right)$ & $98.691(2)$ & $98.620(2)$ & $98.574(4)$ & $98.498(5)$ & $98.469(5)$ \\
\hline Space group, Z & \multicolumn{5}{|c|}{ Trigonal, $\mathrm{P} \quad \mathrm{m} 1$ (164), 1} \\
\hline \multicolumn{6}{|c|}{ Refinement } \\
\hline Nb. reflections & $152 / 2$ & $153 / 2$ & $158 / 2$ & $162 / 2$ & $165 / 2$ \\
\hline $\mathrm{Nb}$. background points & 16 & 14 & 14 & 14 & 14 \\
\hline
\end{tabular}


Nb. refined parameters (w/o bgd pts)

Nb. Wyckoff positions

$\mathrm{Nb}$. atoms

$R_{\mathrm{p}}(\%)$

$R_{\text {wp }}(\%)$

$R_{\text {Bragg }}(\%)$

$R_{\text {exp }}(\%)$

$X^{2}$

Average crystallites size

\begin{tabular}{ccccc}
14 & 14 & 14 & 14 & 14 \\
3 & 3 & 3 & 3 & 3 \\
4 & 5 & 5 & 5 & 5 \\
7.50 & 7.42 & 8.16 & 8.57 & 9.97 \\
8.05 & 7.88 & 8.40 & 8.90 & 10.0 \\
1.81 & 2.14 & 2.73 & 2.92 & 2.71 \\
5.10 & 5.25 & 5.40 & 5.58 & 5.72 \\
2.49 & 2.25 & 2.42 & 2.55 & 3.09 \\
& & & & \\
140 & 114 & 94 & 83 & 78 \\
\hline
\end{tabular}

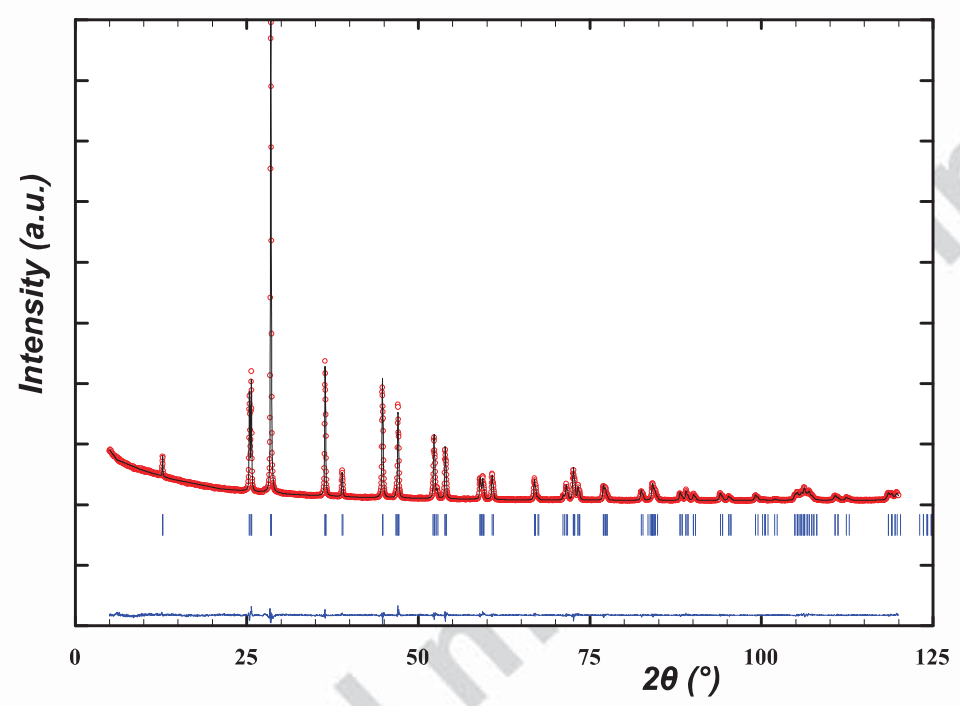

Fig.2. Final Rietveld refinement pattern for $\mathrm{La}_{2} \mathrm{O}_{2} \mathrm{~S}: 1 \% \mathrm{Er}, 0 \% \mathrm{Yb}$ : Observed (dotted line), calculated (black full line) and difference X-ray powder diffraction profiles from the pattern matching plot obtained with Fullprof. The vertical markers correspond to the position of the Bragg reflections.

Table 3

Atomic positions, isotropic atomic displacement parameters and site occupancies for $\mathrm{La}_{2} \mathrm{O}_{2} \mathrm{~S}: 1 \% \mathrm{Er}, 0 \% \mathrm{Yb}$

\begin{tabular}{ccccccc}
\hline & Position & $\mathbf{x}$ & $\mathbf{y}$ & $\mathbf{z}$ & Biso $\left(\AA^{2}\right)$ & occupancy \\
\hline $\mathrm{La}^{3+}$ & $2 d$ & $1 / 3$ & $2 / 3$ & $0.279(1)$ & 0.343 & 0.99 \\
$\mathrm{Er}^{3+}$ & $2 d$ & $1 / 3$ & $2 / 3$ & $0.279(1)$ & 0.343 & 0.01 \\
$\mathrm{O}^{2-}$ & $2 d$ & $1 / 3$ & $2 / 3$ & $0.629(2)$ & 0.423 & 1.00 \\
$\mathrm{~S}^{2-}$ & $1 a$ & 0 & 0 & 0 & 0.587 & 1.00 \\
\hline
\end{tabular}




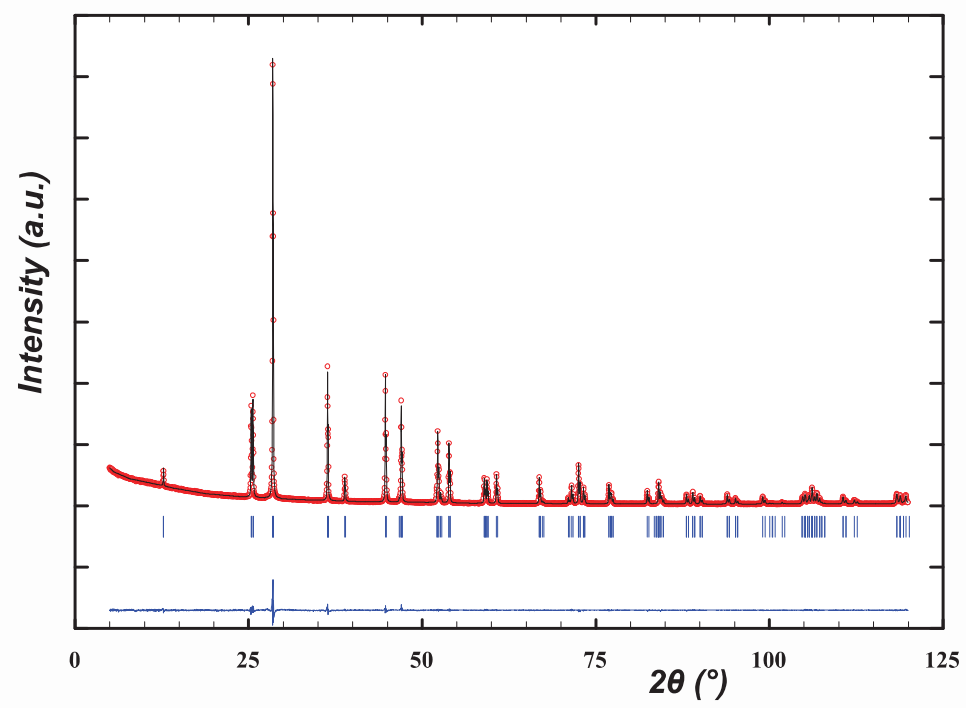

Fig.3. Final Rietveld refinement pattern for $\mathrm{La}_{2} \mathrm{O}_{2} \mathrm{~S}: 1 \% \mathrm{Er}, 3 \% \mathrm{Yb}$ : Observed (dotted line), calculated (black full line) and difference X-ray powder diffraction profiles from the pattern matching plot obtained with Fullprof. The vertical markers correspond to the position of the Bragg reflections.

Table 4

Atomic positions, isotropic atomic displacement parameters and site occupancies for $\mathrm{La}_{2} \mathrm{O}_{2} \mathrm{~S}: 1 \% \mathrm{Er}, 3 \% \mathrm{Yb}$

\begin{tabular}{ccccccc}
\hline & Position & $\mathbf{x}$ & $\mathbf{y}$ & $\mathbf{z}$ & Biso $\left(\AA^{2}\right)$ & occupancy \\
\hline $\mathrm{La}^{3+}$ & $2 d$ & $1 / 3$ & $2 / 3$ & $0.280(1)$ & 0.285 & 0.96 \\
$\mathrm{Er}^{3+}$ & $2 d$ & $1 / 3$ & $2 / 3$ & $0.280(1)$ & 0.285 & 0.01 \\
$\mathrm{Yb}^{3+}$ & $2 d$ & $1 / 3$ & $2 / 3$ & $0.280(1)$ & 0.285 & 0.03 \\
$\mathrm{O}^{2-}$ & $2 d$ & $1 / 3$ & $2 / 3$ & $0.632(2)$ & 0.718 & 1.00 \\
$\mathrm{~S}^{2-}$ & $1 a$ & 0 & 0 & 0 & 0.492 & 1.00 \\
\hline
\end{tabular}

Fig. 4 shows the evolution of the unit cell parameters $a$ and $c$, as well as the cell volume $V$ in $\mathrm{La}_{2} \mathrm{O}_{2} \mathrm{~S}: \mathrm{Er}_{0.1} \mathrm{Yb}$ phosphors as a function of the $\mathrm{Yb}^{3+}$ co-doping concentrations. 


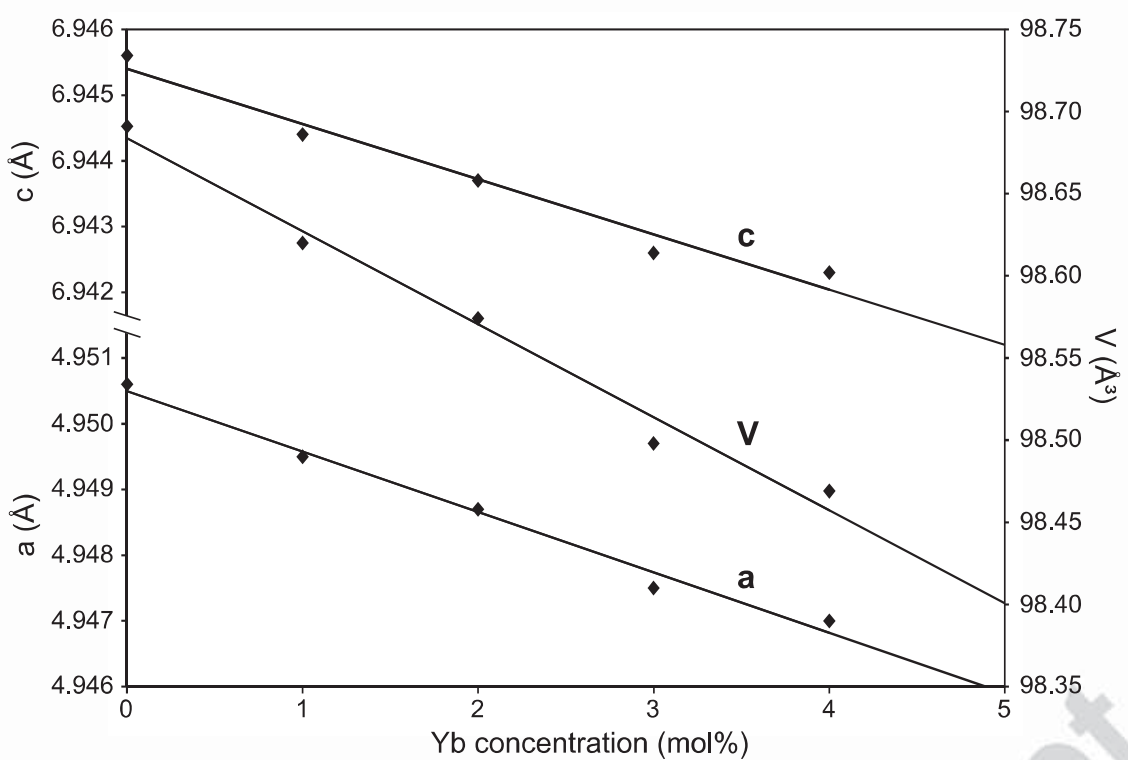

Fig.4. Evolution of the unit cell parameters $a, c$ and cell volume $V$ in $\mathrm{La}_{2} \mathrm{O}_{2} \mathrm{~S}: \mathrm{Er}_{0.1} \mathrm{Yb}$ phosphors as a function of $\mathrm{Yb}^{3+}$ co-doping concentrations.

The linear decrease of the cell parameters $\left(a, c\right.$ and $V$ ) with the $\mathrm{Yb}^{3+}$ doping concentrations confirms the insertion of both $\mathrm{Er}^{3+}$ and $\mathrm{Yb}^{3+}$ within the structure of the host material $\mathrm{La}_{2} \mathrm{O}_{2} \mathrm{~S}$, as it is expected that the average ionic radius of rare earth ions decreases progressively since the dopant ions $\left(\mathrm{r}_{\mathrm{Er}}{ }^{3+}=0.945 \AA, \mathrm{r}_{\mathrm{Yb}}{ }^{3+}=0.925 \AA\right)$ substitute for the $\mathrm{La}^{3+}$ ions $\left(\mathrm{r}_{\mathrm{La}}{ }^{3+}=1.10 \AA\right)$ [44]. Additionally, crystallites sizes have been estimated from the XRD diagrams using the Scherrer equation (1) to be $140,114,94,83$ and $78 \mathrm{~nm}$, respectively in the co-doping concentrations $\mathrm{Er}_{0.01} \mathrm{Yb}_{0.0}, \mathrm{Er}_{0.01} \mathrm{Yb}_{0.01}, \mathrm{Er}_{0.01} \mathrm{Yb}_{0.02}, \mathrm{Er}_{0.01} \mathrm{Yb}_{0.03}$ and $\mathrm{Er}_{0.01} \mathrm{Yb}_{0.04}$

The typical FTIR transmittance spectra of the powder before and after treatment under $\mathrm{H}_{2} \mathrm{~S} / \mathrm{N}_{2}$ were recorded from 400 to $4000 \mathrm{~cm}^{-1}$ and presented in Fig. 5 . 


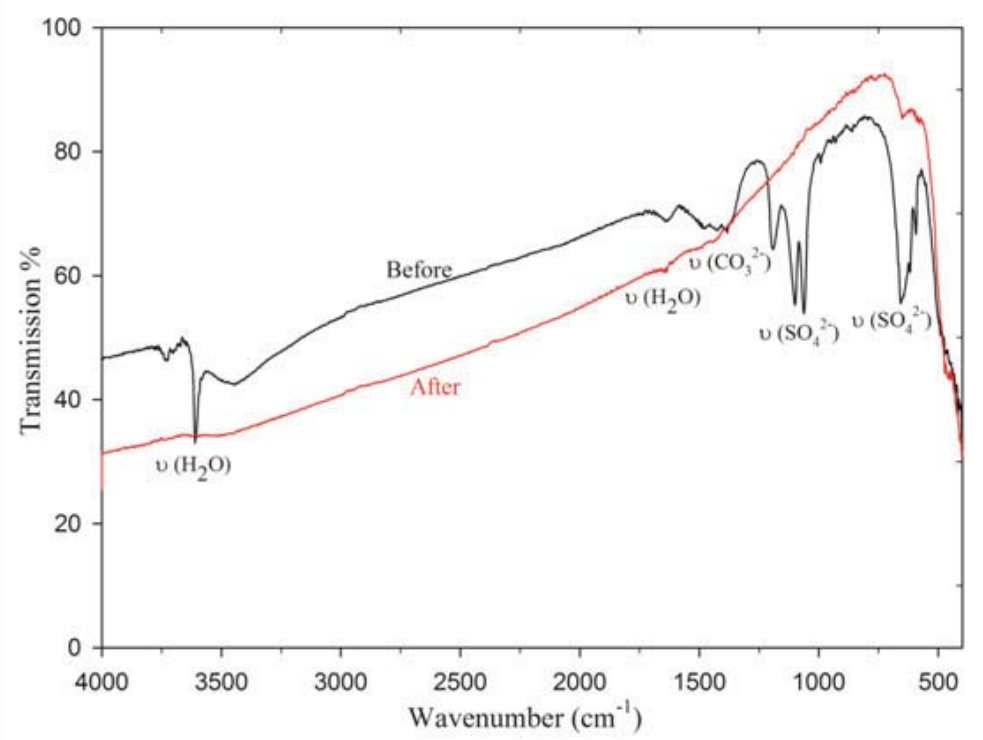

Fig.5. FTIR patterns of $\mathrm{La}_{2} \mathrm{O}_{2} \mathrm{~S}: \mathrm{Er}_{0.1} \mathrm{Yb}_{0.04}$ powders before and after sulfurization

The as-prepared powder spectrum shows strong absorption bands at $3300-3610 \mathrm{~cm}^{-1}$ and 1630 $\mathrm{cm}^{-1}$, characteristics of $v_{3}$ asymmetric and $v_{1}$ symmetric stretching and $v_{2}$ bending modes of the $\mathrm{H}_{2} \mathrm{O}$ molecule, revealing the presence of water $[45,46]$. The stretching vibrations of sulfate groups, observed at $560-700 \mathrm{~cm}^{-1}$ and $1000-1250 \mathrm{~cm}^{-1}$, could be attributed to oxysulfate $\mathrm{La}_{2} \mathrm{O}_{2} \mathrm{SO}_{4}$ previously identified by XRD [47]. Another large band can be observed around 1350$1580 \mathrm{~cm}^{-1}$ due to $\mathrm{C}-\mathrm{O}$ band [48]. It indicates the presence of $\mathrm{CO}_{2}$ adsorbed on $\mathrm{La}_{2} \mathrm{O}_{2} \mathrm{~S}$ particles surface, as already observed for similar compositions [49]. Finally, absorption peaks at 400-550 $\mathrm{cm}^{-1}$ can be attributed respectively to La-O and La-S vibration bands [34]. All the characteristic absorption bands of $\mathrm{H}_{2} \mathrm{O}, \mathrm{SO}_{4}$ and $\mathrm{CO}_{2}$ observed in the as-prepared powder are removed after sulfurization.

The general TGA thermogram of all studied samples is presented in Fig. 6, relative to the composition $\mathrm{La}_{2} \mathrm{O}_{2} \mathrm{~S}: \mathrm{Er}_{0 \cdot 1} \mathrm{Yb}_{0 \cdot 04}$. No significant weight change is observed up to $700^{\circ} \mathrm{C}$. The weight gain between $700^{\circ} \mathrm{C}$ and $1000^{\circ} \mathrm{C}$ is due to the successive transformation of the lanthanum oxysulfide into lanthanum oxysulfate and lanthanum oxide. This result confirms the good 
thermal stability of the $\mathrm{Er}^{3+}, \mathrm{Yb}^{3+}$ co-doped lanthanum oxysulfide from room temperature up to $700^{\circ} \mathrm{C}$.

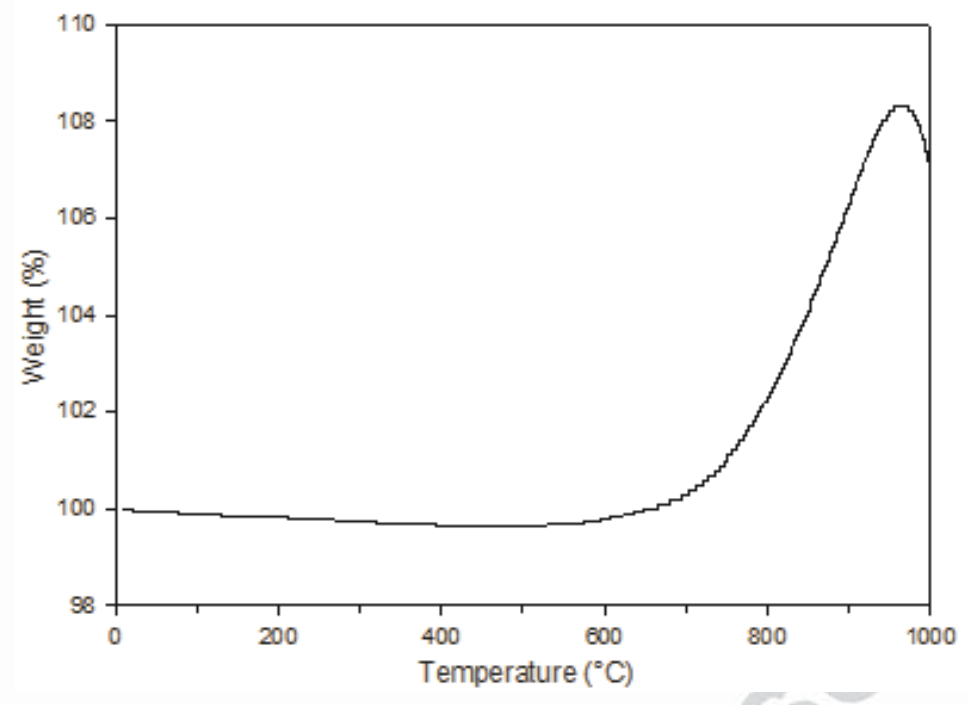

Fig.6. TGA thermogram of $\mathrm{La}_{2} \mathrm{O}_{2} \mathrm{~S}: \mathrm{Er}_{0.1} \mathrm{Yb}_{0.04}$ sample

SEM micrographs of the different powders are very similar; thereby the SEM photographs of one single powder are shown in Fig. 7. 

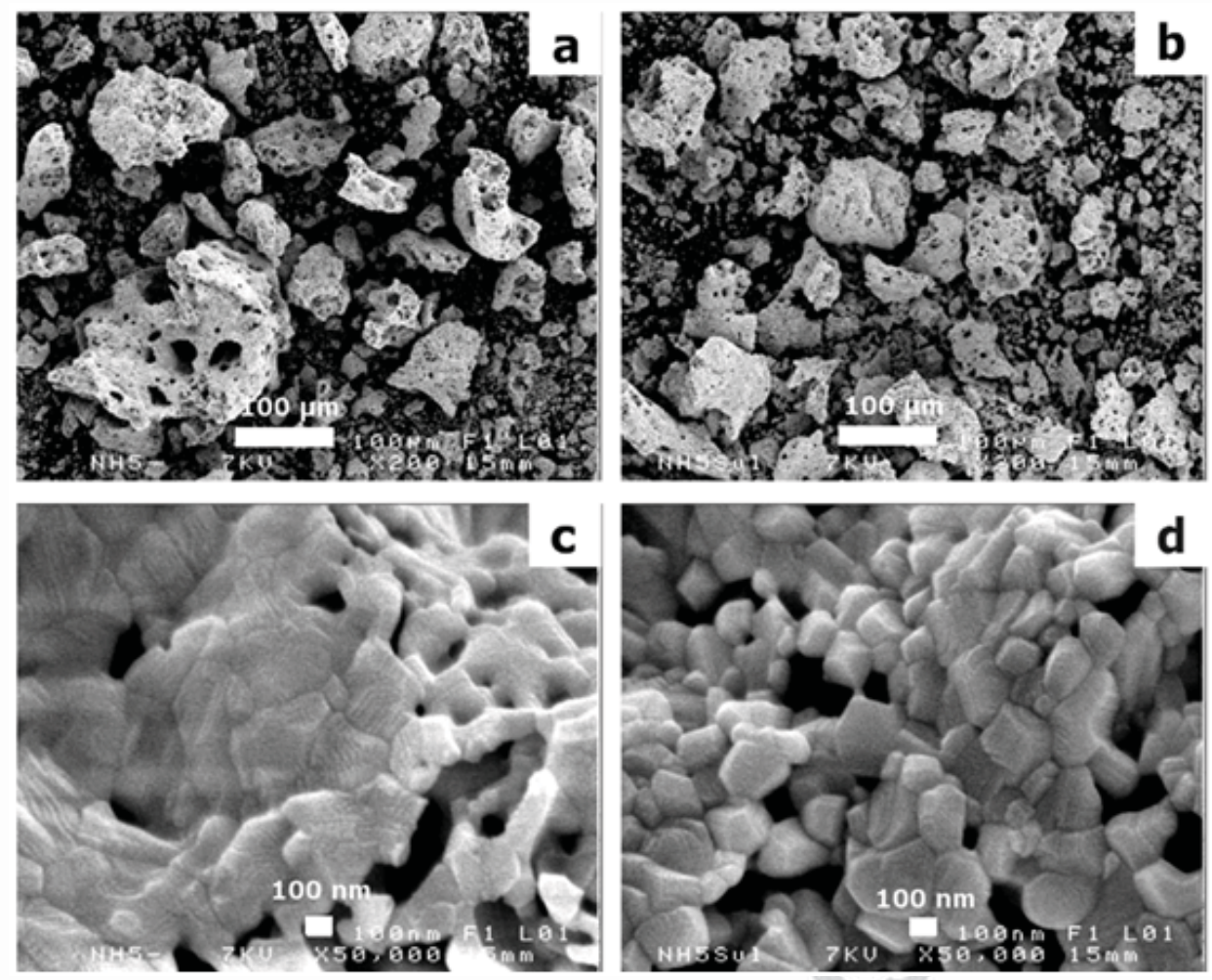

Fig.7. SEM micrographs of $\mathrm{La}_{2} \mathrm{O}_{2} \mathrm{~S}: \mathrm{Er}_{0.1} \mathrm{Yb}_{0.04}$ powders (a),(c) before and (b),(d) after sulfurization

Fig. 7(a) shows that the as-prepared powders consist of porous agglomerates constituting a continuous three-dimensional network which is easy to crush. Porosity arises from the rapid release of gaseous products $\left(\mathrm{NO}_{2}, \mathrm{CO}_{2}\right.$ and $\left.\mathrm{H}_{2} \mathrm{O}\right)$ during combustion. Fig. 7(c) shows that the particles are interconnected by large "necks" revealing a certain degree of sintering due to the high flame temperature reached during the combustion reaction. The size of the agglomerates ranges between $10 \mu \mathrm{m}$ and $500 \mu \mathrm{m}$. SEM images of the powder after treatment under $\mathrm{H}_{2} \mathrm{~S} / \mathrm{N}_{2}$ are shown in Fig. 7 (b) and (d). Due to an etching effect caused by the heat treatment, "grain boundaries" appear more visible which helps identify grains individually. Interestingly, we can observe that the post-heat treatment at $1000^{\circ} \mathrm{C}$ does not affect the grain size distribution in which the average grain size remains nanometric in the order of $50-200 \mathrm{~nm}$. This observation is in good agreement with the average crystallite size estimation obtained by XRD analysis. 


\subsection{Transmission, UPL spectra and decay curves}

Transmission spectra of $\mathrm{La}_{2} \mathrm{O}_{2} \mathrm{~S}: \mathrm{Er}_{0.01} \mathrm{Yb}_{0.0}$ and $\mathrm{La}_{2} \mathrm{O}_{2} \mathrm{~S}: \mathrm{Er}_{0.01} \mathrm{Yb}_{0.04}$ sulfurized samples which were diluted in $\mathrm{KBr}$ pellets were first performed in order to point out the characteristic absorption of $\mathrm{Yb}^{3+}$ at $980 \mathrm{~nm}$ and the most intense absorption of $\mathrm{Er}^{3+}$ at $520 \mathrm{~nm}$, related to the $\mathrm{Yb}^{3+2} \mathrm{~F}_{7 / 2} \rightarrow{ }^{2} \mathrm{~F}_{5 / 2}$ and the $\mathrm{Er}^{3+4} \mathrm{I}_{15 / 2} \rightarrow{ }^{2} \mathrm{H}_{11 / 2}$ transitions, respectively (Fig. 8). The absorption of $\mathrm{Er}^{3+}$ around $1000 \mathrm{~nm}$ (the ${ }^{4} \mathrm{I}_{15 / 2} \rightarrow{ }^{4} \mathrm{I}_{11 / 2}$ transition) cannot be clearly identified due to its much smaller oscillator strength $\left(0.96 \times 10^{-6}\right)$ compared with that of the ${ }^{4} \mathrm{I}_{15 / 2} \rightarrow{ }^{2} \mathrm{H}_{11 / 2}$ transition $(12.86 \mathrm{x}$ $10^{-6}$ ), according to the Judd-Ofelt analysis in $\mathrm{La}_{2} \mathrm{O}_{2} \mathrm{~S}$ : $\mathrm{Er}[50]$. The transmission spectra show that the co-doping of $\mathrm{Yb}^{3+}$ significantly increases the absorption around $1000 \mathrm{~nm}$.

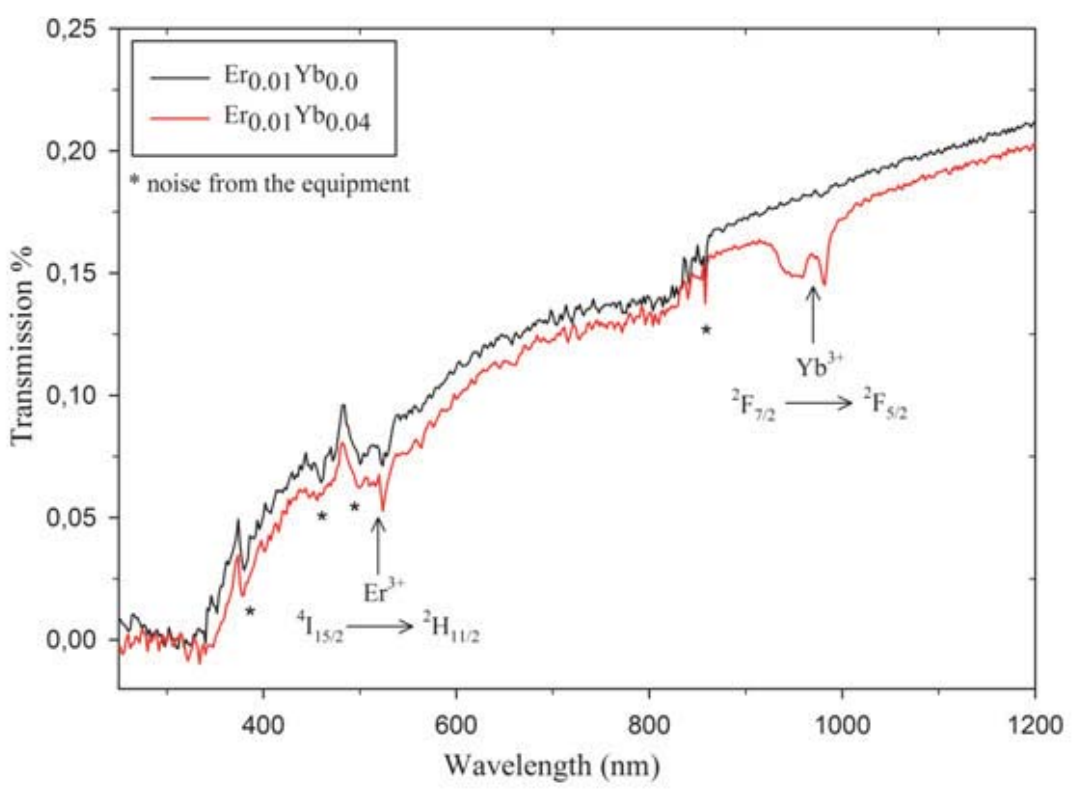

Fig.8. Transmission spectra of $\mathrm{La}_{2} \mathrm{O}_{2} \mathrm{~S}: \mathrm{Er}_{0.1} \mathrm{Yb}_{0.0}$ and $\mathrm{La}_{2} \mathrm{O}_{2} \mathrm{~S}: \mathrm{Er}_{0.1} \mathrm{Yb}_{0.04}$ powders

Fig. 9 shows the UPL spectra of the whole batch of sulfurized $\mathrm{La}_{2} \mathrm{O}_{2} \mathrm{~S}_{\mathrm{Yb}}{ }^{3+}, \mathrm{Er}^{3+}$ with excitation at $980 \mathrm{~nm}$. It can be seen that the UPL spectra present an up-conversion luminescence phenomenon as first reported by Auzel. This UPL by $\mathrm{Yb}^{3+}-\mathrm{Er}^{3+}$ is termed as energy transfer upconversion (ETU), where a host with low phonon energy is required in order to impair the fast 
non-radiative relaxation of the first excited state (the $\mathrm{Er}^{3+}{ }^{4} \mathrm{I}_{11 / 2}$ level). The appearance of UPL in our samples is ascribed to the low phonon energy of $\mathrm{La}_{2} \mathrm{O}_{2} \mathrm{~S}$ whose maximum is $500 \mathrm{~cm}^{-1}$ [8].

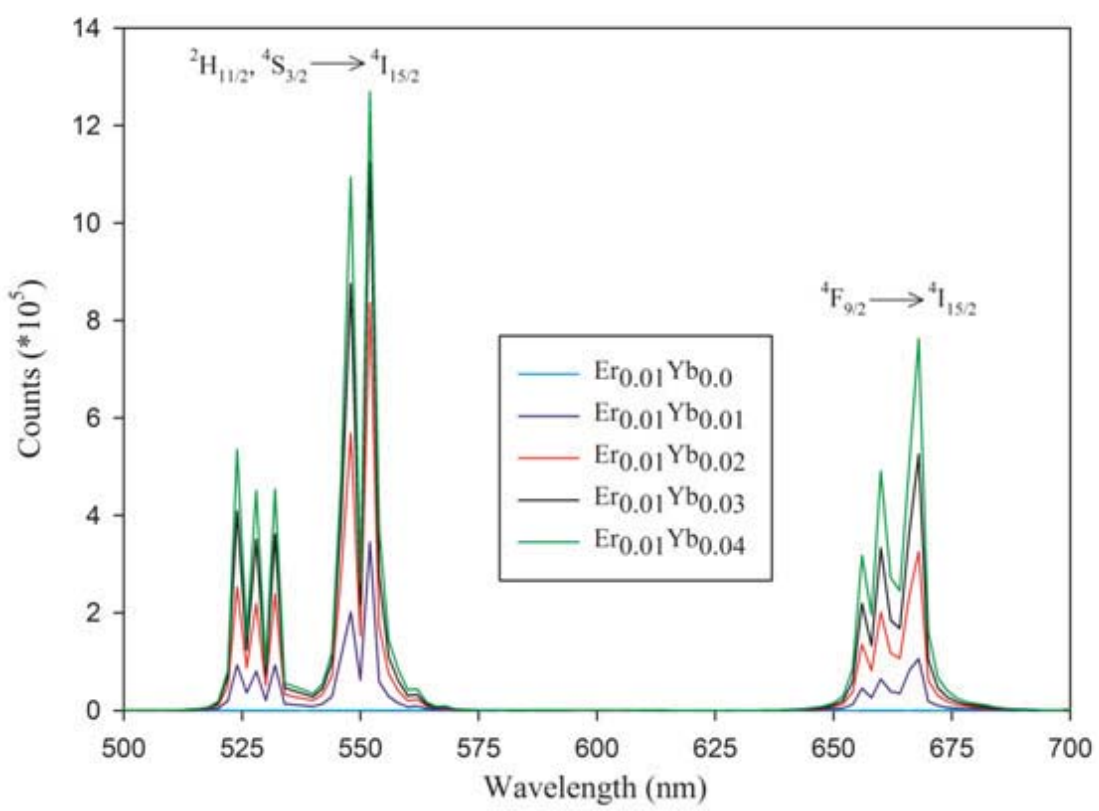

Fig.9. Up-conversion luminescence spectra of $\mathrm{La}_{2} \mathrm{O}_{2} \mathrm{~S}: \mathrm{Er}^{3+}, \mathrm{Yb}^{3+}$ powders (excitation at $980 \mathrm{~nm}$ )

The energy level diagram in Fig. 10 schematizes the mechanism of UPL in our samples. Nearinfrared radiation is absorbed by $\mathrm{Yb}^{3+}\left({ }^{2} \mathrm{~F}_{7 / 2} \rightarrow{ }^{2} \mathrm{~F}_{5 / 2}\right)$ and transferred to the $\mathrm{Er}^{3+}$ ion, so that its ${ }^{4} \mathrm{I}_{11 / 2}$ level is populated. During the lifetime of the ${ }^{4} \mathrm{I}_{11 / 2}$ level, a second photon is absorbed by $\mathrm{Yb}^{3+}$ and the energy is transferred to $\mathrm{Er}^{3+}$ raising the latter from the ${ }^{4} \mathrm{I}_{11 / 2}$ level to the ${ }^{4} \mathrm{~F}_{7 / 2}$ level. Then, it decays rapidly and non-radiatively to the ${ }^{2} \mathrm{H}_{11 / 2}$ level from which a green emission occurs $\left({ }^{2} \mathrm{H}_{11 / 2} \rightarrow{ }^{4} \mathrm{I}_{15 / 2}\right)$. A second non-radiative transition to the ${ }^{4} \mathrm{~S}_{3 / 2}$ level appears, leading to a second green emission $\left({ }^{4} \mathrm{~S}_{3 / 2} \rightarrow{ }^{4} \mathrm{I}_{15 / 2}\right)$. Another emission, less intense, exists also in the red due to the transition between the ${ }^{4} \mathrm{~F}_{9 / 2} \rightarrow{ }^{4} \mathrm{I}_{15 / 2}$ levels. Two main processes can occur which populate the ${ }^{4} \mathrm{~F}_{9 / 2}\left(\mathrm{Er}^{3+}\right)$ energy level and result in the red emission. One mechanism is the non-radiative transition from ${ }^{4} \mathrm{I}_{11 / 2}$ energy level to ${ }^{4} \mathrm{I}_{13 / 2}$ energy level, followed by the absorption of a $980 \mathrm{~nm}$ photon which will excite an electron from the ${ }^{4} \mathrm{I}_{13 / 2}$ level to the ${ }^{4} \mathrm{~F}_{9 / 2}$ level. A second mechanism 
will be several de-excitations of an electron from an upper level, as for example, the ${ }^{4} \mathrm{~F}_{7 / 2}$ level to the ${ }^{4} \mathrm{~F}_{9 / 2}$ level. In a low phonon energy host such as $\mathrm{La}_{2} \mathrm{O}_{2} \mathrm{~S}$, the non-radiative transition can be suppressed. As a result, the relative intensity of the red emission is smaller than the green emissions in our samples.

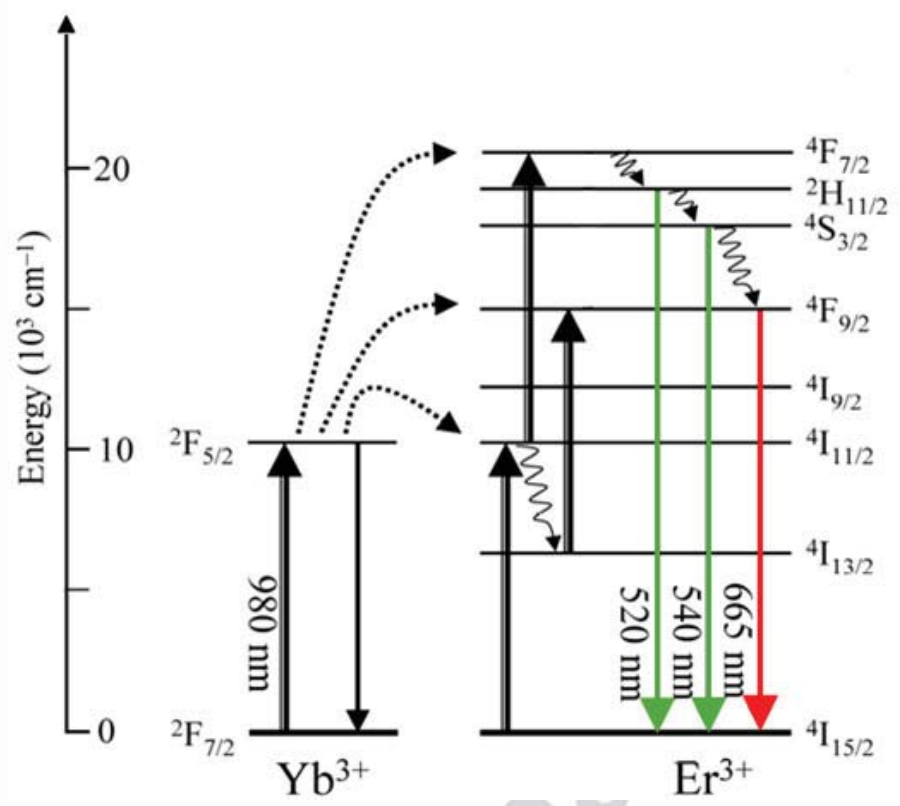

Fig.10. Schematic energy levels diagram of $\mathrm{Er}^{3+}$ and $\mathrm{Yb}^{3+}$ in $\mathrm{La}_{2} \mathrm{O}_{2} \mathrm{~S}$

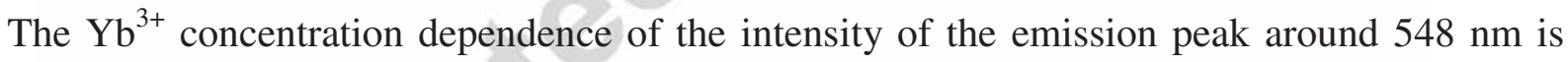
studied (Fig. 11). Even though the UPL from $980 \mathrm{~nm}$ can take place in the samples singly-doped with $\mathrm{Er}^{3+}$ (not observed in our samples), a significantly more intense UPL can be achieved by $\mathrm{Yb}^{3+}-\mathrm{Er}^{3+}$ co-doping. It is owing to the large absorption cross-section of the $\mathrm{Yb}^{3+}$ at $980 \mathrm{~nm}$, as shown in Fig. 8, and to the effective energy transfer from the sensitizer $\left(\mathrm{Yb}^{3+}\right)$ to the activator $\left(\mathrm{Er}^{3+}\right)$. It can be seen on Fig. 9 and Fig. 11 that the intensity of UPL increases with the concentration of $\mathrm{Yb}^{3+}$. In order to increase the efficiency of the ETU process, the activator ions $\mathrm{Er}^{3+}$ should be surrounded by as many sensitizer ions $\mathrm{Yb}^{3+}$ as possible. However, the dopant ions must be diluted with a sufficient number of inactive ions $\left(\mathrm{La}^{3+}\right.$ in the host material) to limit energy migration from active ions to killer traps, which cause quenching of the desired 
luminescence. According to UPL spectra, the concentration quenching effect of the sensitizer is not significant in our samples since no decrease of emission intensity is observed even in the sample with highest $\mathrm{Yb}^{3+}$ doping concentration.

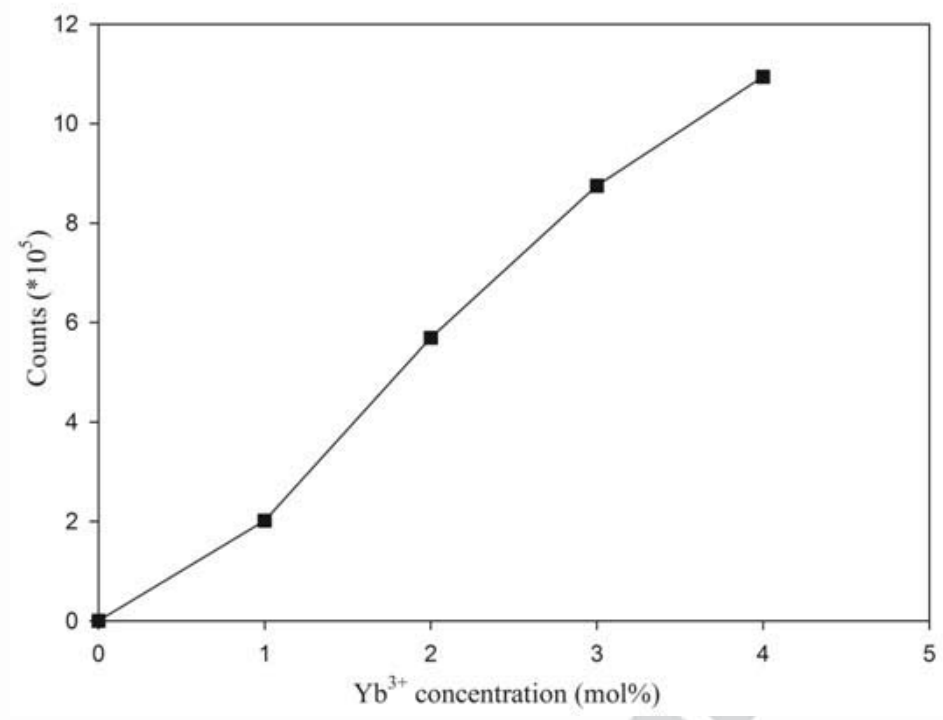

Fig.11. Green emission intensity at $548 \mathrm{~nm}$ of $\mathrm{La}_{2} \mathrm{O}_{2} \mathrm{~S}: \mathrm{Er}_{0,1} \mathrm{Yb}$ phosphors as a function of $\mathrm{Yb}^{3+}$ co-doping concentrations (mol\%)

The decay curves of the $\mathrm{Er}^{3+}{ }^{4} \mathrm{~S}_{3 / 2}$ level are measured under the excitation at $380 \mathrm{~nm}$ in order to observe the possible de-excitation from the level ${ }^{4} \mathrm{~S}_{3 / 2}\left(\mathrm{Er}^{3+}\right)$ to the level ${ }^{2} \mathrm{~F}_{5 / 2}\left(\mathrm{Yb}^{3+}\right)$ (Fig. 12).

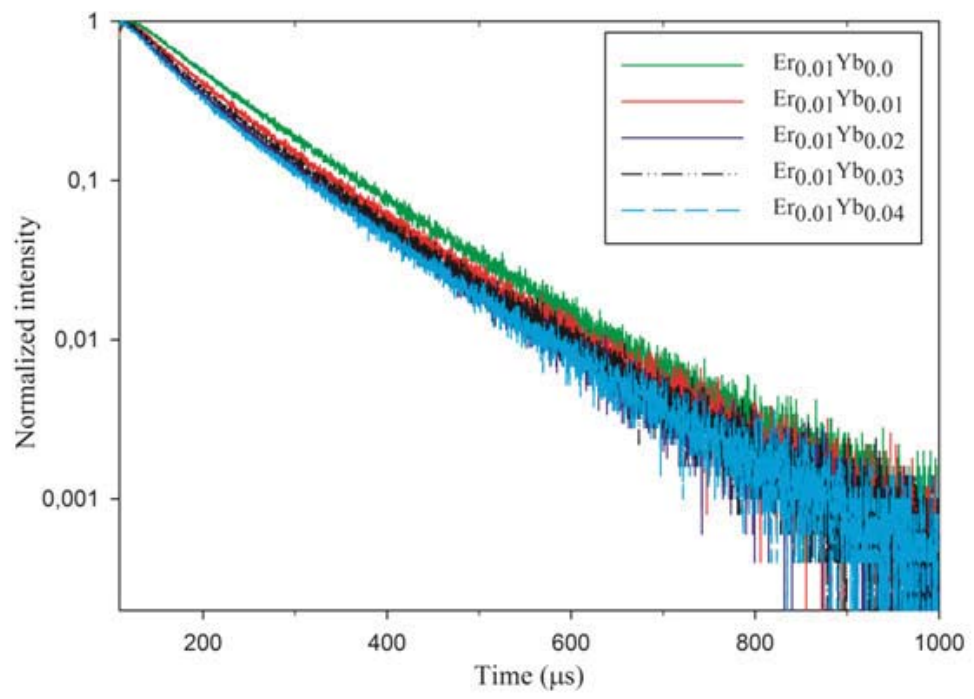

Fig.12. Emission decay curves of the ${ }^{4} \mathrm{~S}_{3 / 2} \rightarrow{ }^{4} \mathrm{I}_{15 / 2}$ transition for the $\mathrm{La}_{2} \mathrm{O}_{2} \mathrm{~S}: \mathrm{Er}^{3+}, \mathrm{Yb}^{3+}$ phosphors 
The decay curves show a quasi-linear behavior indicating a limited back energy transfer from $\mathrm{Er}^{3+}$ to $\mathrm{Yb}^{3+}$. The integral average lifetime of the $\mathrm{Er}^{3+}{ }^{4} \mathrm{~S}_{3 / 2}$ level is calculated from the decay curves (Fig. 13). With the increase of $\mathrm{Yb}^{3+}$ concentration, the lifetime of the $\mathrm{Er}^{3+}{ }^{4} \mathrm{~S}_{3 / 2}$ level remains almost constant. It indicates that when the $\mathrm{Yb}^{3+}$ concentration is less than $4 \mathrm{~mol} \%$, the non-radiative relaxation rate of the $\mathrm{Er}^{3+}{ }^{4} \mathrm{~S}_{3 / 2}$ level concerned with $\mathrm{Yb}^{3+}$ concentration is limited. It is ascribed to the fact that the energy transfer from the $\mathrm{Er}^{3+}{ }^{4} \mathrm{~S}_{3 / 2}$ level back to the $\mathrm{Yb}^{3+}{ }^{2} \mathrm{~F}_{5 / 2}$ level is not efficient, which has been recently pointed out in $\mathrm{NaYF}_{4} / \mathrm{Er}, \mathrm{Yb}$ [51].

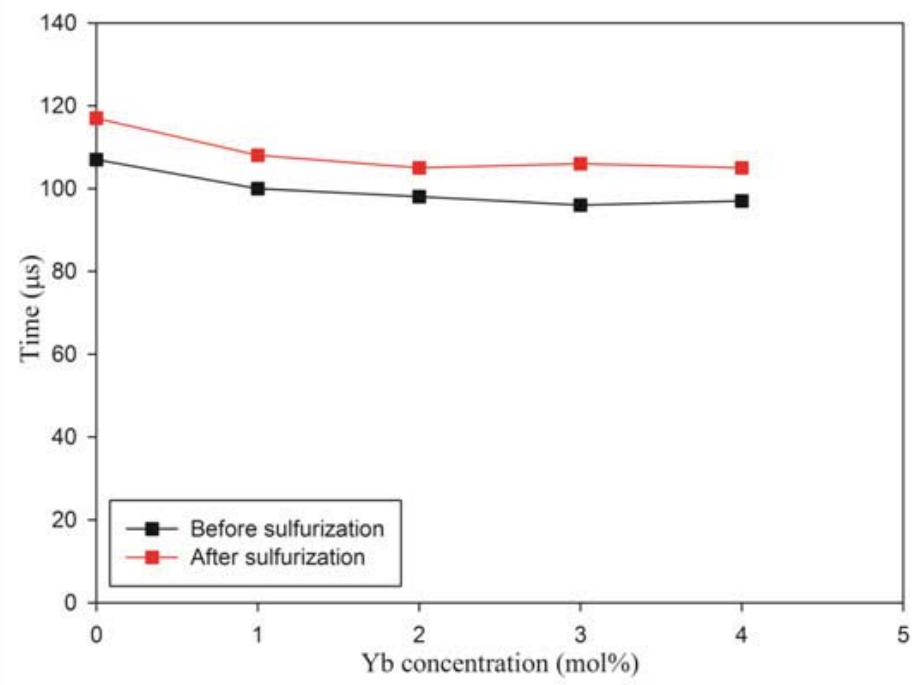

Fig.13. Evolution of the lifetime of the $\mathrm{Er}^{3+}{ }^{4} \mathrm{~S}_{3 / 2}$ level $\tau(\mu \mathrm{s})$ as a function of $\mathrm{Yb}^{3+}$ concentration in $\operatorname{La}_{2} \mathrm{O}_{2} \mathrm{~S}: \mathrm{Er}_{0.1} \mathrm{Yb}$ phosphors

The relative emission efficiency of the powders $\mathrm{La}_{2} \mathrm{O}_{2} \mathrm{~S}: \mathrm{Er}_{0.01} \mathrm{Yb}_{0.04}$, before and after sulfurization, was estimated according to the formula:

$$
\frac{\eta(\text { sulfurized powder })}{\eta(\text { raw powder })}=\frac{A_{\text {sulf }}^{\mathrm{e}}}{A_{\text {raw }}^{e}} / \frac{A_{\text {sulf }}^{\mathrm{a}}}{A_{\text {raw }}^{\mathrm{a}}}
$$

where $A^{e}$ (Fig. 14) and $A^{a}$ (Fig. 15) are the emission (548nm) and absorption (980nm) peaks areas, respectively. A ratio of 1.605 (>1) was obtained; this value demonstrates the improvement of the emission efficiency after sulfurization. This amelioration is ascribed to the elimination of the oxide and oxysulfate phases which interfere in the phenomenon of the up-conversion by 
decreasing its intensity. Moreover, increased crystallinity induced by the post-annealing treatment at $1000^{\circ} \mathrm{C}$ for $2 \mathrm{~h}$ can advantageously yield an increased efficiency of the phosphor particles, hence the importance of the sulfurization step.

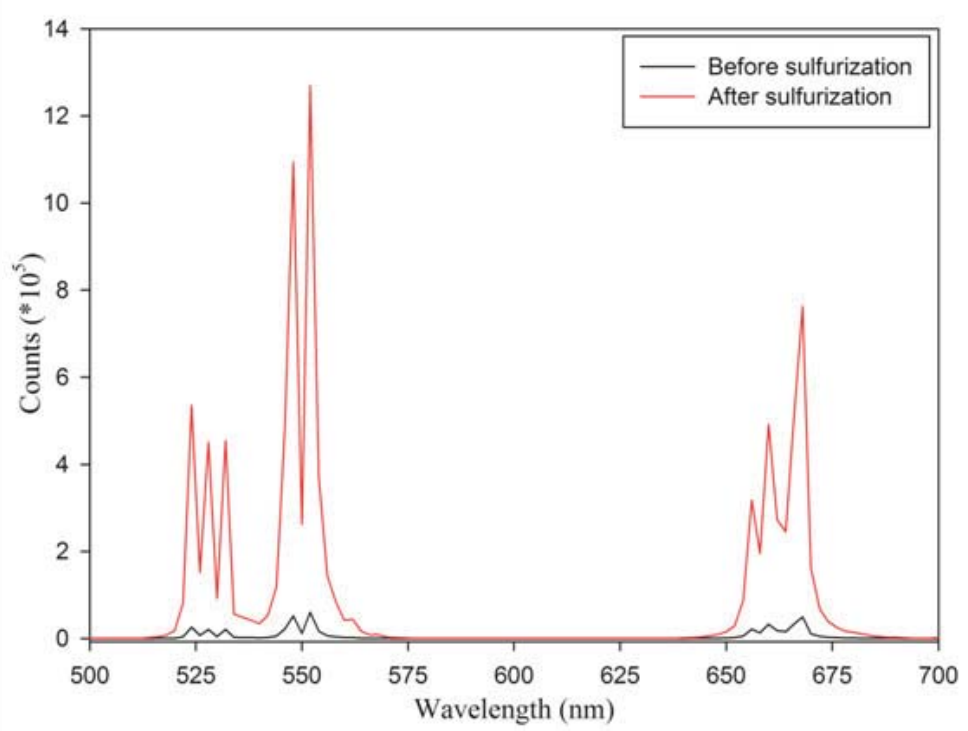

Fig.14. Emission spectra of $\mathrm{La}_{2} \mathrm{O}_{2} \mathrm{~S}: \mathrm{Er}_{0.1} \mathrm{Yb}_{0.04}$ powders before and after sulfurization

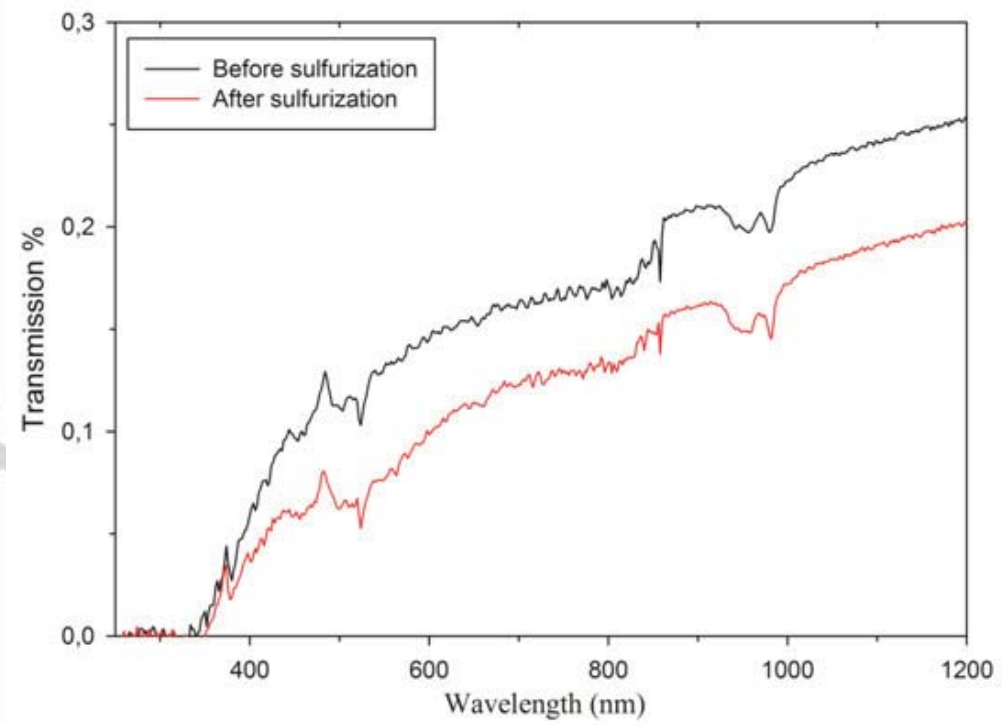

Fig.15. Transmission spectra of $\mathrm{La}_{2} \mathrm{O}_{2} \mathrm{~S}: \mathrm{Er}_{0.1} \mathrm{Yb}_{0.04}$ powders before and after sulfurization 
In addition, according to the emission decay curves of the ${ }^{4} \mathrm{~S}_{3 / 2} \rightarrow{ }^{4} \mathrm{I}_{15 / 2}$ transition for powders before and after sulfurization (Fig. 13 and Fig. 16), the increase of lifetime after sulfurization indicates a suppression of non-radiative relaxation due to the elimination of by-products, which can explain the increase of emission efficiency.

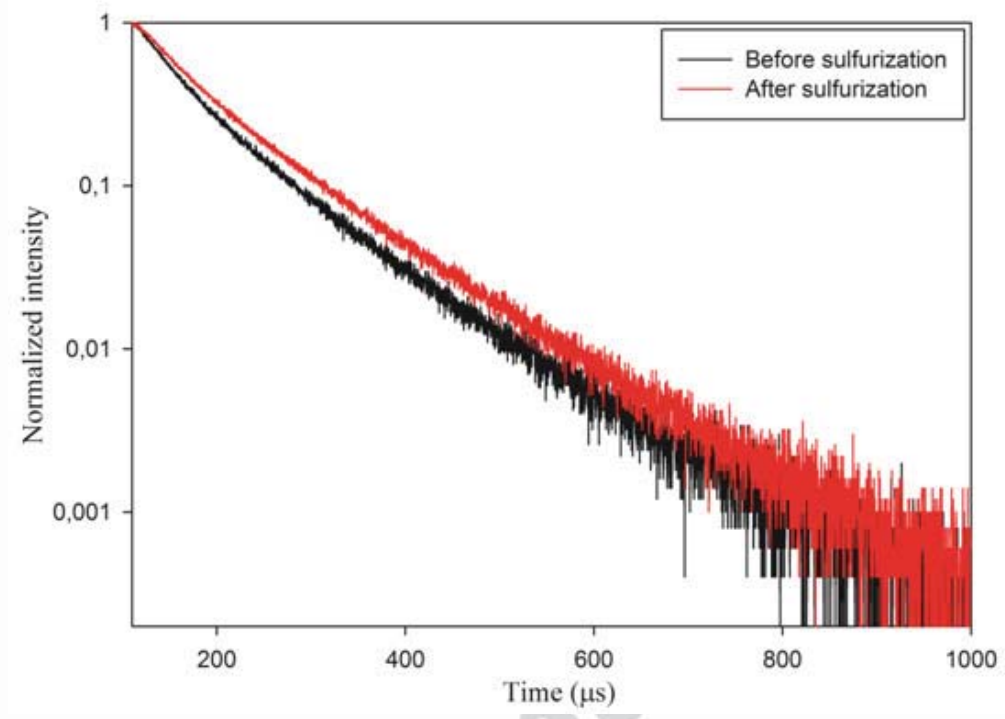

Fig.16. Emission decay curves of the ${ }^{4} \mathrm{~S}_{3 / 2} \rightarrow{ }^{4} \mathrm{I}_{15 / 2}$ transition for the $\mathrm{La}_{2} \mathrm{O}_{2} \mathrm{~S}: \mathrm{Er}_{0.1} \mathrm{Yb}_{0.04}$ powders before and after sulfurization

\section{Conclusions}

In this study, a combustion method has been successfully developed, for the first time, for the production of $\mathrm{La}_{2} \mathrm{O}_{2} \mathrm{~S}: \mathrm{Er}^{3+}, \mathrm{Yb}^{3+}$ up-converter nanophosphors. XRD and FTIR results attested the formation of high-purity and well-crystallized $\mathrm{La}_{2} \mathrm{O}_{2} \mathrm{~S}: \mathrm{Er}^{3+}, \mathrm{Yb}^{3+}$ after post-treatment of the as-prepared powders in a $\mathrm{H}_{2} \mathrm{~S} / \mathrm{N}_{2}$ flow for $2 \mathrm{~h}$ at $1000^{\circ} \mathrm{C}$ which, in addition, did not induce crystal growth. SEM observations confirmed that the average particle size remained unchanged in the order of $50-200 \mathrm{~nm}$. 
Crystallographic analysis also revealed the formation of a continuous solid solution, within the investigated co-dopant concentrations, with the insertion of both $\mathrm{Er}^{3+}$ and $\mathrm{Yb}^{3+}$ within the host structure by substitution for the $\mathrm{La}^{3+}$ ions.

The efficient energy transfer from $\mathrm{Yb}^{3+}$ to $\mathrm{Er}^{3+}$ results in a strong up-conversion upon excitation at $980 \mathrm{~nm}$. The emission spectra show the intense green emissions corresponding to the $\left({ }^{2} \mathrm{H}_{11 / 2},{ }^{4} \mathrm{~S}_{3 / 2}\right) \rightarrow{ }^{4} \mathrm{I}_{15 / 2}$ transitions and a red emission corresponding to the ${ }^{4} \mathrm{~F}_{9 / 2} \rightarrow{ }^{4} \mathrm{I}_{15 / 2}$ transition. In addition, the increase of $\mathrm{Yb}^{3+}$ concentration leads to a significantly more intense UPL thanks to the absence of significant concentration quenching effect and back energy transfer. Finally, it is demonstrated that the sulfurization treatment brings about considerable enhancement of UPL efficiency through suppression of non-radiative relaxation and enhanced crystallinity.

The synthesis procedure and post-treatment developed in this study produced highly efficient $\mathrm{La}_{2} \mathrm{O}_{2} \mathrm{~S}: \mathrm{Yb}^{3+}, \mathrm{Er}^{3+}$ up-convertors which may find promising applications and developments, in particular as a novel generation of luminescent labels. 


\section{References}

[1] Q. Liu, Y. Sun, T. Yang, W. Feng, C. Li, F. Li, J. Am. Chem. Soc. 133 (2011) 1712217125.

[2] S.F. Lim, R. Riehn, C.-K. Tung, W.S. Ryu, R. Zhuo, J. Dalland, R.H. Austin, Nanotechnol. 20 (2009) 405701.

[3] L. Xiong, Z. Chen, Q. Tian, T. Cao, C. Xu, F. Li, Anal. Chem. 81 (2009) 8687-8694.

[4] Y. Yang, Microchim Acta 181 (2014) 263-294.

[5] T. Trupke, M.A. Green, P. Würfel, J. Appl. Phys. 92 (2002) 4117-4122.

[6] P. Gibart, F. Auzel, J.C. Guillaume, K. Zahraman, Japanese J. Appl. Phys. 35(8) (1996) 4401-4402.

[7] F. Wang, X. Liu, Chem. Soc. Rev., 38 (2009) 976-989.

[8] C. De Mello Donega, A. Meijerink, G. Blasse, J. Phys. Chem. Solids 56 (1995) 673-685.

[9] S.S. Trond, J.S. Martin, J.P. Stavanage, A.L. Smith, J. Electrochem. Soc. 116 (1969) 10471050.

[10] G.I. Abutalibov, D.I. Guseynov, A.A. Mamedov, Phys. Status Solidi C 6 (2009) 11271129.

[11] R.V. Alves, R.A. Buchanan, K.A. Wickersheim, E.A.C. Yates, J. Appl. Phys. 42 (1971) 3043-3048.

[12] Yu.V. Orlovskii, T.T. Basiev, K.K. Pukhov, M.V. Polyachenkova, P.P. Fedorov, O.K. Alimov, E.I. Gorokhova, V.A. Demidenko, O.A. Khristich, R.M. Zakalyukin, J. Lumin. 125 (2007) 201-215.

[13] G.A. Kumar, M. Pokhrel, A. Martinez, D.K. Sardar, Sci. Adv. Mate. 4 (2012) 623-630.

[14] S.A. Hilderbrand, F. Shao, C. Salthouse, U. Mahmood, R. Weissleder, Chem. Commun., (2009) 4188-4190.

[15] F. Wang, X. Liu, J. Am. Chem. Soc., 130 (2008) 5642-5643. 
[16] M. Wang, G. Abbineni, A. Clevenger, C. Mao, S. Xu, Nanomedicine 7 (2011) 710-729.

[17] F. Auzel, C.R. Acad. Sc., Paris, B, 262 (1966) 1016-1019.

[18] G. Blasse, B.C. Grabmaier, Luminescent Materials, Springer-Verlag, Berlin, 1994, p. 197.

[19] T. Riuttamäki, Annales Universitatis Turkuensis, Sarja-Ser. A/OSA-TOM.427 (2011).

[20] M. Pokhrel, G.A. Kumar, D.K. Sardar, J. Mater. Chem. A 1 (2013) 11595-11606.

[21] M. Kottaisamy, R. Jagannathan, R.P. Rao, M. Avudaithai, L.K. Srinivasan, L.K. Sundaram, J. Electrochem. Soc. 142 (1995) 3205-3209.

[22] M. Kottaisamy, K. Horikawa, H. Kominami, T. Aoki, N. Azuma, T. Nakamura, Y. Nakanishi, Y. Hatanaka, J. Electrochem. Soc. 147 (2000) 1612-1616.

[23] Luuji Ozawa, J. Electrochem. Soc. 124 (1977) 413-417.

[24] K. Ikeue, T. Kawano, M. Eto, D. Zhang, M. Machida, J. Alloys Compd. 451 (2008) 338340.

[25] M. Pham-Thi, A. Morell, J. Electrochem. Soc. 138 (1991) 1100-1103.

[26] J.W. Haynes, J.J. Brown, J. Electrochem. Soc. 115 (1968) 1060-1066.

[27] A.M. Pires, O.A. Serra, M.R. Davolos, J. Alloys Compd. 374 (2004) 181-184.

[28] B.M. Tissue, Chem. Mater. 10 (1998) 2837-2845.

[29] E.T. Goldburt, B. Kulkami, R.N. Bhargava, J. Taylor, M. Libera, J. Lumin. 72-74 ( 1997) 190-192.

[30] S.-H. Yu, Z.-H. Han, J. Yang, H.-Q. Zhao, R.-Y. Yang, Y. Xie, Y.-T. Qian, Y.-H. Zhang, Chem. Mater. 11 (1999) 192-194.

[31] Z. Liu, X. Sun, S. Xu, J. Lian, X. Li, Z. Xiu, Q. Li, D. Huo, J.-G. Li, J. Phys. Chem. C 112 (2008) 2353-2358.

[32] J. Dhanaraj, M. Geethalakshmi, R. Jagannathan, T.R.N. Kutty, Chem. Phys. Lett. 387 (2004) 23-28. 
[33] H. Peng, S. Huang, F. You, J. Chang, S. Lu, L. Cao, J. Phys. Chem. B 109 (2005) 57745778.

[34] X.-X Luo, W.-H. Cao, J. Alloys Compd. 460 (2008) 529-534.

[35] J.J. Kingsley, L.R. Pederson, Mater. Res. Soc. Symp. Proc. 296 (1993) 361-366.

[36] J. Bang, M. Abboudi, B. Abrams, P.H. Holloway, J. Lumin. 106 (2004) 177-185.

[37] T. Xia, W.-H. Cao, X.X. Luo, Y. Tian, J. Mater. Res. 20 (2005) 2274-2278.

[38] L. Ozawa, P.M. Jaffe, J. Electrochem.Soc. 117 (1970) 1297-1301.

[39] J. Rodriguez-Carvajal, Physica B, 192 (1993) 55.

[40] B. Morosin, Acta Cryst., B29 (1973) 2647.

[41] J.F. Berar, P. Lelann, J. Appl. Cryst. 24 (1991) 1-5.

[42] J.F. Berar, Acc. In Pow. Diff. II, NIST sp.Pub.846 (1992) 63.

[43] P. Scherrer, Nach. Gesell. Wissens. Gott. Math. Phys., 1-2 (1918) 96-100.

[44] R.D. Shannon, Acta Cryst. A32 (1976) 751-767.

[45] A. Janca, K. Tereszchuk, P.F. Bernath, N.F. Zobov, S.V. Shirin, O.L. Polyansky, J. Tennyson, J. Mol. Spectrosc. 219 (2003) 132-135.

[46] R. Lemus, J. Mol. Spectrosc. 225 (2004) 73-92.

[47] R.A. Nyquist, R.O. Kagel, C. Putzig, A. Leugers, The Handbook of Infrared and Raman Spectra of Inorganic Compounds and Organic Salts, Academic Press:San Diego, CA, 1996.

[48] J.A. Capobianco, F. Vetrone, T. D'Alesio, G. Tessari, A. Speghini, M. Bettinelli, Phys. Chem. Chem. Phys. 2 (2000) 3203-3207.

[49] B. Fan, C. Chlique, O.Merdrignac-Conanec, X. Zhang, X. Fan, J. Phys. Chem. C 116 (2012) 11652-11657.

[50] S. Buddhudu, F.J. Bryant, J. Less-Common Met. 147 (1989) 213-225.

[51] L. Aarts, B.M. van der Ende, A. Meijerink, J. Appl. Phys. 106 (2009) 023522. 
Table 1

$\mathrm{Er}^{3+}, \mathrm{Yb}^{3+}$ co-doping concentrations (mol\%) in $\mathrm{La}_{2} \mathrm{O}_{2} \mathrm{~S}$ powders.

\begin{tabular}{lll}
\hline Sample & $\mathrm{Er}(\mathrm{mol} \%)$ & $\mathrm{Yb}(\mathrm{mol} \%)$ \\
\hline $\mathrm{Er}_{0.01} \mathrm{Yb}_{0.0}$ & 1 & 0 \\
$\mathrm{Er}_{0.01} \mathrm{Yb}_{0.01}$ & 1 & 1 \\
$\mathrm{Er}_{0.01} \mathrm{Yb}_{0.02}$ & 1 & 2 \\
$\mathrm{Er}_{0.01} \mathrm{Yb}_{0.03}$ & 1 & 3 \\
$\mathrm{Er}_{0.01} \mathrm{Yb}_{0.04}$ & 1 & 4 \\
\hline
\end{tabular}


Table 2

Details of the Rietveld refinement and average crystallites size for the $\mathrm{La}_{2} \mathrm{O}_{2} \mathrm{~S}: 1 \% \mathrm{Er}, \mathrm{x} \% \mathrm{Yb}$

\begin{tabular}{|c|c|c|c|c|c|}
\hline Yb (\%) & $0 \%$ & $1 \%$ & $2 \%$ & $3 \%$ & $4 \%$ \\
\hline Lattice & & & & & \\
\hline $\mathrm{a}(\AA)$ & $4.0506(1)$ & $4.0495(1)$ & $4.0487(1)$ & $4.0475(1)$ & $4.0470(2)$ \\
\hline$c(\AA)$ & $6.9456(1)$ & $6.9444(2)$ & $6.9437(2)$ & $6.9426(3)$ & $6.9423(3)$ \\
\hline Volume $\left(\AA^{3}\right)$ & $98.691(2)$ & $98.620(2)$ & $98.574(4)$ & $98.498(5)$ & $98.469(5)$ \\
\hline Space group, Z & \multicolumn{5}{|c|}{ Trigonal, $\mathrm{P} \quad \mathrm{m} 1$ (164), 1} \\
\hline \multicolumn{6}{|l|}{ Refinement } \\
\hline $\mathrm{Nb}$. reflections & $152 / 2$ & $153 / 2$ & $158 / 2$ & $162 / 2$ & $165 / 2$ \\
\hline $\mathrm{Nb}$. background points & 16 & 14 & 14 & 14 & 14 \\
\hline $\mathrm{Nb}$. refined parameters (w/o bgd pts) & 14 & 14 & 14 & 14 & 14 \\
\hline Nb. Wyckoff positions & 3 & 3 & 3 & 3 & 3 \\
\hline $\mathrm{Nb}$. atoms & 4 & 5 & 5 & 5 & 5 \\
\hline$R_{\mathrm{p}}(\%)$ & 7.50 & 7.42 & 8.16 & 8.57 & 9.97 \\
\hline$R_{\mathrm{wp}}(\%)$ & 8.05 & 7.88 & 8.40 & 8.90 & 10.0 \\
\hline$R_{\text {Bragg }}(\%)$ & 1.81 & 2.14 & 2.73 & 2.92 & 2.71 \\
\hline$R_{\exp }(\%)$ & 5.10 & 5.25 & 5.40 & 5.58 & 5.72 \\
\hline$x^{2}$ & 2.49 & 2.25 & 2.42 & 2.55 & 3.09 \\
\hline \multicolumn{6}{|l|}{ Average crystallites size } \\
\hline$<\mathrm{L}>(\mathrm{nm})$ & 140 & 114 & 94 & 83 & 78 \\
\hline
\end{tabular}


Table 3

Atomic positions, isotropic atomic displacement parameters and site occupancies for $\mathrm{La}_{2} \mathrm{O}_{2} \mathrm{~S}: 1 \% \mathrm{Er}, 0 \% \mathrm{Yb}$

\begin{tabular}{ccccccc}
\hline & Position & $\mathbf{x}$ & $\mathbf{y}$ & $\mathbf{z}$ & Biso $\left(\AA^{2}\right)$ & occupancy \\
\hline $\mathrm{La}^{3+}$ & $2 d$ & $1 / 3$ & $2 / 3$ & $0.279(1)$ & 0.343 & 0.99 \\
$\mathrm{Er}^{3+}$ & $2 d$ & $1 / 3$ & $2 / 3$ & $0.279(1)$ & 0.343 & 0.01 \\
$\mathrm{O}^{2-}$ & $2 d$ & $1 / 3$ & $2 / 3$ & $0.629(2)$ & 0.423 & 1.00 \\
$\mathrm{~S}^{2-}$ & $1 a$ & 0 & 0 & 0 & 0.587 & 1.00 \\
\hline
\end{tabular}


Table 4

Atomic positions, isotropic atomic displacement parameters and site occupancies for $\mathrm{La}_{2} \mathrm{O}_{2} \mathrm{~S}: 1 \% \mathrm{Er}, 3 \% \mathrm{Yb}$

\begin{tabular}{ccccccc}
\hline & Position & $\mathbf{x}$ & $\mathbf{y}$ & $\mathbf{z}$ & Biso $\left(\AA^{2}\right)$ & occupancy \\
\hline $\mathrm{La}^{3+}$ & $2 d$ & $1 / 3$ & $2 / 3$ & $0.280(1)$ & 0.285 & 0.96 \\
$\mathrm{Er}^{3+}$ & $2 d$ & $1 / 3$ & $2 / 3$ & $0.280(1)$ & 0.285 & 0.01 \\
$\mathrm{Yb}^{3+}$ & $2 d$ & $1 / 3$ & $2 / 3$ & $0.280(1)$ & 0.285 & 0.03 \\
$\mathrm{O}^{2-}$ & $2 d$ & $1 / 3$ & $2 / 3$ & $0.632(2)$ & 0.718 & 1.00 \\
$\mathrm{~S}^{2-}$ & $1 a$ & 0 & 0 & 0 & 0.492 & 1.00 \\
\hline
\end{tabular}




\section{Figures captions}

Fig.1. XRD patterns of $\mathrm{La}_{2} \mathrm{O}_{2} \mathrm{~S}: \mathrm{Er}_{0.1} \mathrm{Yb}_{0.04}$ powders before and after sulfurization

Fig.2. Final Rietveld refinement pattern for $\mathrm{La}_{2} \mathrm{O}_{2} \mathrm{~S}: 1 \% \mathrm{Er}, 0 \% \mathrm{Yb}$ : Observed (dotted line), calculated (black full line) and difference X-ray powder diffraction profiles from the pattern matching plot obtained with Fullprof. The vertical markers correspond to the position of the Bragg reflections.

Fig.3. Final Rietveld refinement pattern for $\mathrm{La}_{2} \mathrm{O}_{2} \mathrm{~S}: 1 \% \mathrm{Er}, 3 \% \mathrm{Yb}$ : Observed (dotted line), calculated (black full line) and difference X-ray powder diffraction profiles from the pattern matching plot obtained with Fullprof. The vertical markers correspond to the position of the Bragg reflections.

Fig.4. Evolution of the unit cell parameters $a, c$ and cell volume $V$ in $\mathrm{La}_{2} \mathrm{O}_{2} \mathrm{~S}: \mathrm{Er}_{0.1} \mathrm{Yb}$ phosphors as a function of $\mathrm{Yb}^{3+}$ co-doping concentrations.

Fig.5. FTIR patterns of $\mathrm{La}_{2} \mathrm{O}_{2} \mathrm{~S}: \mathrm{Er}_{0.1} \mathrm{Yb}_{0.04}$ powders before and after sulfurization

Fig.6. TGA thermogram of $\mathrm{La}_{2} \mathrm{O}_{2} \mathrm{~S}: \mathrm{Er}_{0.1} \mathrm{Yb}_{0.04}$ sample

Fig.7. SEM micrographs of $\mathrm{La}_{2} \mathrm{O}_{2} \mathrm{~S}: \mathrm{Er}_{0.1} \mathrm{Yb}_{0.04}$ powders (a),(c) before and (b),(d) after sulfurization

Fig.8. Transmission spectra of $\mathrm{La}_{2} \mathrm{O}_{2} \mathrm{~S}: \mathrm{Er}_{0.1} \mathrm{Yb}_{0.0}$ and $\mathrm{La}_{2} \mathrm{O}_{2} \mathrm{~S}: \mathrm{Er}_{0.1} \mathrm{Yb}_{0.04}$ powders

Fig.9. Up-conversion luminescence spectra of $\mathrm{La}_{2} \mathrm{O}_{2} \mathrm{~S}: \mathrm{Er}^{3+}, \mathrm{Yb}^{3+}$ powders (excitation at $980 \mathrm{~nm}$ )

Fig.10. Schematic energy levels diagram of $\mathrm{Er}^{3+}$ and $\mathrm{Yb}^{3+}$ in $\mathrm{La}_{2} \mathrm{O}_{2} \mathrm{~S}$ 
Fig.11. Green emission intensity at $548 \mathrm{~nm}$ of $\mathrm{La}_{2} \mathrm{O}_{2} \mathrm{~S}: \mathrm{Er}_{0.1} \mathrm{Yb}$ phosphors as a function of $\mathrm{Yb}^{3+}$ co-doping concentrations $(\mathrm{mol} \%)$

Fig.12. Emission decay curves of the ${ }^{4} \mathrm{~S}_{3 / 2} \rightarrow{ }^{4} \mathrm{I}_{15 / 2}$ transition for the $\mathrm{La}_{2} \mathrm{O}_{2} \mathrm{~S}: \mathrm{Er}^{3+}, \mathrm{Yb}^{3+}$ phosphors

Fig.13. Evolution of the lifetime of the $\mathrm{Er}^{3+}{ }^{4} \mathrm{~S}_{3 / 2}$ level $\tau(\mu \mathrm{s})$ as a function of $\mathrm{Yb}^{3+}$ concentration in $\mathrm{La}_{2} \mathrm{O}_{2} \mathrm{~S}: \mathrm{Er}_{0.1} \mathrm{Yb}$ phosphors

Fig.14. Emission spectra of $\mathrm{La}_{2} \mathrm{O}_{2} \mathrm{~S}: \mathrm{Er}_{0.1} \mathrm{Yb}_{0.04}$ powders before and after sulfurization

Fig.15. Transmission spectra of $\mathrm{La}_{2} \mathrm{O}_{2} \mathrm{~S}: \mathrm{Er}_{0.1} \mathrm{Yb}_{0.04}$ powders before and after sulfurization

Fig.16. Emission decay curves of the ${ }^{4} \mathrm{~S}_{3 / 2} \rightarrow{ }^{4} \mathrm{I}_{15 / 2}$ transition for the $\mathrm{La}_{2} \mathrm{O}_{2} \mathrm{~S}: \mathrm{Er}_{0.1} \mathrm{Yb}_{0.04}$ powders before and after sulfurization 
Up-conversion luminescence of $\mathrm{La}_{2} \mathrm{O}_{2} \mathrm{~S}: \mathrm{Er}^{3+}, \mathrm{Yb}^{3+}$ nanophosphors prepared by combustion synthesis 


\section{Highlights}

- $\mathrm{La}_{2} \mathrm{O}_{2} \mathrm{~S}: \mathrm{Er} 3+, \mathrm{Yb} 3+$ up-converter nanophosphors were prepared by combustion synthesis.

- The synthesis method results in phosphor nanoparticles of the order of 50-200nm.

- Energy transfer from Yb3+ to Er3+ results in a strong UPL upon excitation at $980 \mathrm{~nm}$.

- No concentration quenching effect and back energy transfer were evidenced.

- We report the importance of the post-treatment in a $\mathrm{H}_{2} \mathrm{~S} / \mathrm{N}_{2}$ flow on UPL efficiency. 


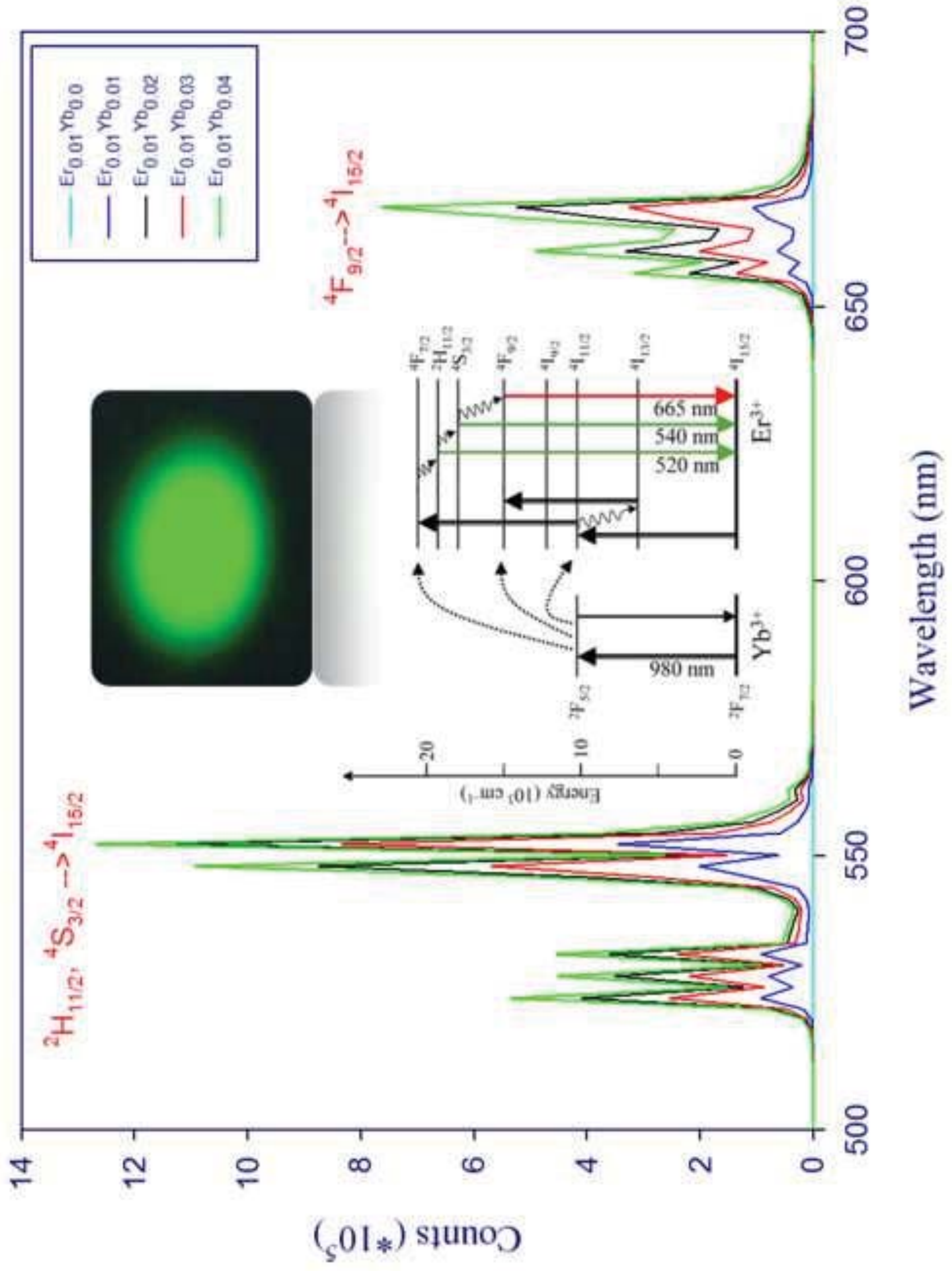

